\title{
Engineered Zero-Dimensional Fullerene/Carbon Dots-Polymer Based Nanocomposite Membranes for Wastewater Treatment
}

\author{
Mona Jani ${ }^{1, *}$, Jose A. Arcos-Pareja ${ }^{1}$ and Ming $\mathrm{Ni}^{2, *}$ a() \\ 1 Department of Physical Sciences and Nanotechnology, Yachay Tech University, 100119 Urcuquí, Ecuador; \\ jose.arcos@yachaytech.edu.ec \\ 2 GeneScript, Zhenjiang, Jiangsu 212000, China \\ * Correspondence: mjani@yachaytech.edu.ec (M.J.); Ming1.Ni@genscript.com (M.N.)
}

Academic Editor: Minas M. Stylianakis

Received: 21 February 2020; Accepted: 13 April 2020; Published: 26 October 2020

\begin{abstract}
With the rapid growth of industrialization, diverse pollutants produced as by-products are emitted to the air-water ecosystem, and toxic contamination of water is one of the most hazardous environmental issues. Various forms of carbon have been used for adsorption, electrochemical, and ion-exchange membrane filtration to separation processes for water treatment. The utilization of carbon materials has gained tremendous attention as they have exceptional properties such as chemical, mechanical, thermal, antibacterial activities, along with reinforcement capability and high thermal stability, that helps to maintain the ecological balance. Recently, engineered nano-carbon incorporated with polymer as a composite membrane has been spotlighted as a new and effective mode for water treatment. In particular, the properties of zero-dimensional (0D) carbon forms (fullerenes and carbon dots) have encouraged researchers to explore them in the field of wastewater treatment through membrane technologies as they are biocompatible, which is the ultimate requirement to ensure the safety of drinking water. Thus, the purpose of this review is to highlight and summarize current advances in the field of water purification/treatment using 0D carbon-polymer-based nanocomposite membranes. Particular emphasis is placed on the development of $0 \mathrm{D}$ carbon forms embedded into a variety of polymer membranes and their influence on the improved performance of the resulting membranes. Current challenges and opportunities for future research are discussed.
\end{abstract}

Keywords: fullerenes; carbon dots; biocompatibility; 0D carbon-polymer nanocomposite membranes; water treatment

\section{Introduction}

Hygienic water is vital for the ecological environment and human health. Vast amounts of water deteriorated by contaminants are discharged from industry or through intensification of human activity, thus it is significant to implement conventional water treatments, resource recovery and purification technologies [1]. Increasing demands for advanced water treatments have stimulated an intensive exploration for use of high-performance membrane-based technologies. Membrane-based technologies are exceptionally attractive as they are highly efficient, have low energy consumption, easy scale-up feasibility and have a small carbon footprint [2,3]. Diverse membrane-based technologies have been used for the treatment of water, including micro/ultra/nano-filtration $(\mu \mathrm{F} / \mathrm{UF} / \mathrm{NF})$, reverse osmosis and membrane distillation [4]. A common driving force for membrane separation is pressure [5]. Amongst membrane-based technologies, the most common one is commercialized reverse osmosis, which is based on pressure driving forces, consumes high energy and has high operational costs, thus hindering its wider application [6]. For the development of these membrane-based technologies for water purification, 
membranes made of polymeric materials are attracting increased research interest. Polymeric membranes are energy efficient, can be easily scaled, offer time-saving processes, they are highly permeable to water, have stable structures, are highly water selective, have excellent solute rejection at low operation pressures and are sturdily resistant to oxidation and fouling. Aside from polymer membrane technology, other known processes to purify water are distillation, electrolysis/dialysis, adsorption, chemical oxidation, ion exchange, and biological remediation. For the formation of polymer membranes, polymers such as polyvinylidene difluoride, sulfone polymers, polyacrylonitrile, polyvinyl alcohol/chloride, polyethylene/propylene/ amide, and chitosan are preferred. Some preparation methods for forming polymeric membranes are electrospinning [7], track-etching, stretching, vapor deposition, sol-gel process, phase inversion, and interfacial polymerization (IP) [8]. Thin film composite (TFC) membranes are fabricated using IP, which is essential for commercialization of reverse osmosis and NF processes. Most of these membranes produced via IP have polyamide as a skinny layer on the upper part of a membrane support. The active monomers used to form functional polyamide skinny layers are commonly $m$-phenylenediamine and trimesoyl chloride. The synthetic pathway for preparation of membranes is shown in Scheme 1. The polyamide membranes derived from monomers have good desalination properties [9].

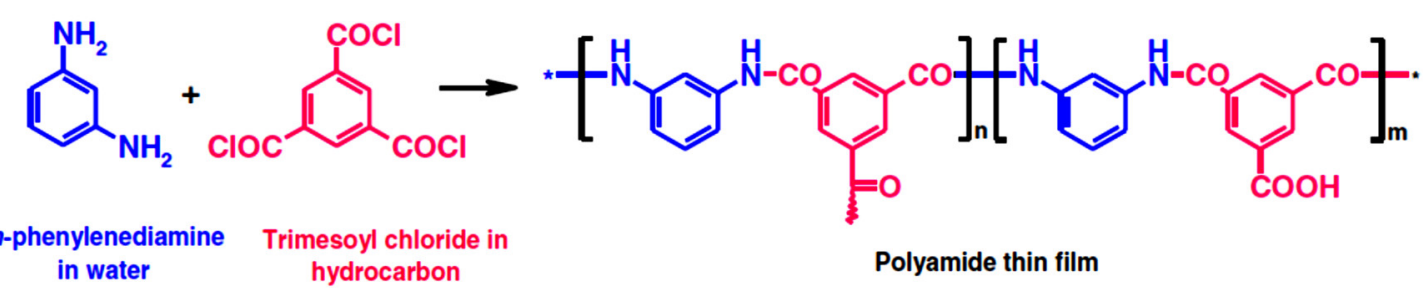

Scheme 1. Commercial polyamide membrane derived from monomers such as $m$-phenylenediamine and trimesoyl chloride via IP. Reproduced with permission from [9]. Crown copyright $@ 2020$ published by Elsevier B.V.

Properties of membranes such as crystallinity, structure, hydrophobicity/hydrophilicity, surface charge and roughness affect their permeate flux, flux rejection, and fouling performances. Most polymer-based water separation membranes are fabricated based on their surface properties that are porous super hydrophobic or hydrophilic [10]. The antifouling properties of hydrophilic membranes are better than those of hydrophobic membranes [11]. Generally, a membrane with higher permeate flux recovery rates exhibits better antifouling properties. The major drawbacks of the available polymer-based membranes are the fouling of membranes caused by the adsorption of surfactants, plugging of pores and structural degradation after long periods in use. The fouling properties depend on the surface characteristics of membranes such as their porosity, hydrophobicity, size and morphology of pores [12]. For hydrophobic membranes, surface roughness and a low surface energy are essential [13], and are achieved by precise surface treatments. With the incorporation of nanomaterials, the surface roughness is increased, and thus polymer nanocomposite membranes are formed. In general, knowledge of nanotechnology comes from the basic elements with certain characteristics. Further, nanotechnology encompasses terms such as nanoscale (about 1-100 nm) and nanomaterials (nano-objects and nanostructured). Nano-objects have dimensions in the nanoscale range, whereas, nanostructured materials have an internal core structure or surface structure that lies in the nanoscale range. When the nanoscale and nanomaterials are jointly present in a polymer/non-polymer matrix they form nanocomposites. Nanocomposites can be defined as nanomaterials which have a multiphase structure which consists of at least one phase of nanoscale dimensions. Nanomaterial properties such as large surface for adsorption, unique surface chemistry, photo- catalysis, antimicrobial, super-paramagnetic, electric and optical properties are beneficial for improving the properties of the resulting material. Nanomaterials could be organic, inorganic compounds or composites. For improving the hydrophilicity and antifouling properties, approaches implemented include IP [14], coating on substrate membranes [15,16], incorporating in situ hydrophilic surface modifying macromolecules [17], 
grafting [18], blending, or using hydrophilic polymers and monomers [19-21], etc. Incorporating various forms of carbon nanofillers to form polymer composite membranes is one of the membrane modification methods. Several nanofillers such as $\mathrm{SiO}_{2}, \mathrm{Al}_{2} \mathrm{O}_{3}, \mathrm{Au}$, zeolites, $\mathrm{Fe}, \mathrm{Ag}, \mathrm{TiO}_{2}, \mathrm{ZnO}$, polyhedral oligomeric silsesquioxanes, metal-organic frameworks, etc., are currently used for the formation of nanocomposite polymer membranes. Compared to all these materials, it is critical to know that materials of a carbonaceous nature are environmentally friendly, have low toxicity, facile preparations, they are abundantly available and have excellent biocompatibility. Carbon-based materials are organic compounds containing carbon atoms that exist in the form of spheres, sheets, ellipsoids, nanobuds/ribbons, and hollow tubes. Fullerenes, carbon nanotubes, carbon nanofibers, carbon black, graphene, nanodiamond, CDs, carbon onions, etc. all have different structures and bonding and are the known carbon forms. Carbon nano-forms can be produced in various shapes such as spheres, tubes, sheets, dots and so on. The shape, size and surface properties of nanofillers are important factors affecting the nanocomposite membrane performance, mainly reduced solute selectivity and performance stability.

Carbon-based polymer nanocomposite membranes have recently attracted significant attention for wastewater treatment and purification, mostly for removal of microorganisms, chemical compounds, heavy metals, and separation of oil from water. Figure 1 presents the trend in publications using carbon-polymer nanocomposites developed for wastewater treatment. It can be seen from the figure that the research in the area of wastewater treatment using carbon-polymer nanocomposites is relatively new and the research progress is boosted from 2016 onwards.

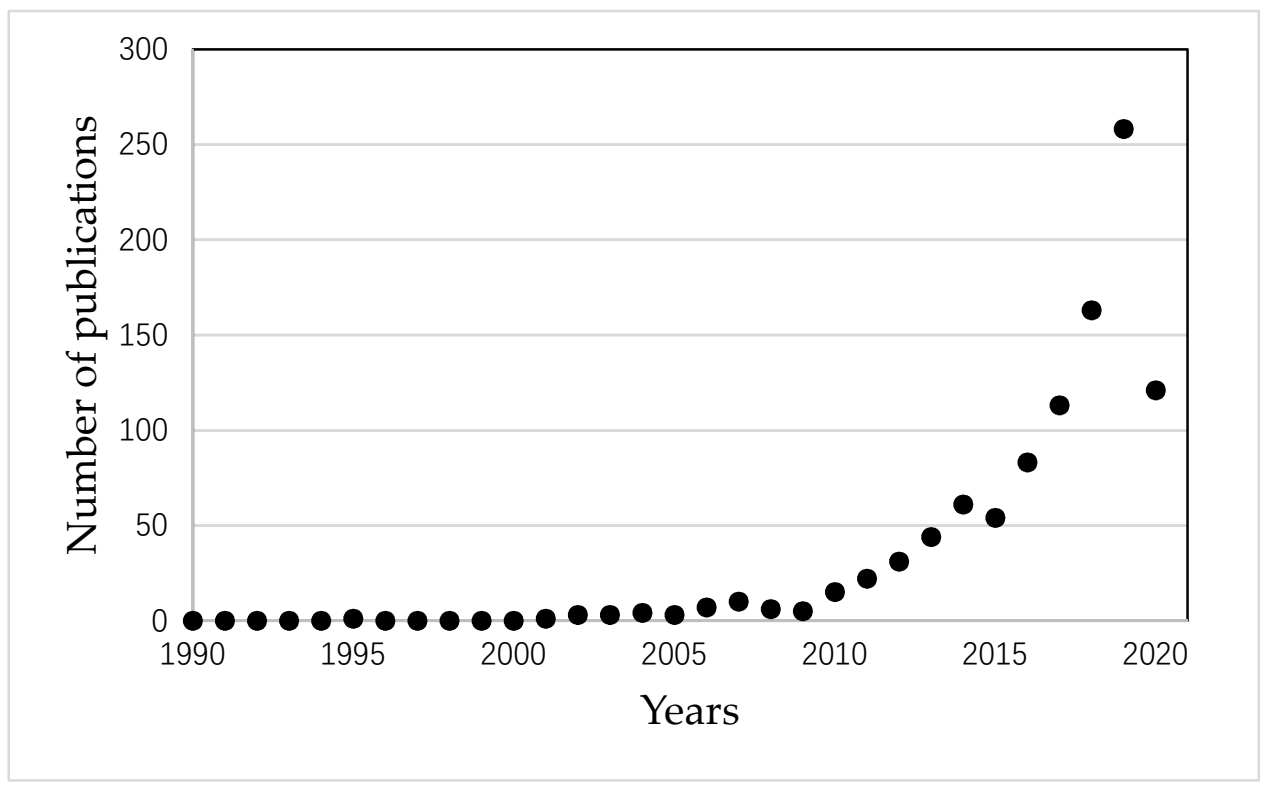

Figure 1. Publication trends from 1990-2020 in the field of carbon-polymer nanocomposites for wastewater treatment (Source: Google Scholar, data extracted on 31.3.2020).

With the usage of the carbon nanomaterials it is possible to achieve desirable pore size, larger surface area, and unique surface functionalities that further provides opportunities to enhance the water permeability, thermomechanical stability, improving hydrophilicity, and antifouling properties of polymer-based nanocomposite membranes [22]. All the forms of carbon nanomaterials are biocompatible [23-25]. Surface functionalization and interactions of carbon nanomaterials with polymers and approaches to enhance the carbon-polymer interface for the bio-environment have been described in [26] in detail. Antibacterial and photocatalysis characteristics of carbon nanomaterials add advantages to improve the membrane functionality. Consequently, a substantial primary challenge for membrane research lies in improving permeability, rejection, stability and antifouling of carbon-polymer 
nanocomposite membranes [27-29], with a proper characterization of the carbon and carbon-polymer matrix interfaces during loading and assessing the efficiency of load transfer in the nanocomposites.

Looking at the current prerequisites, amongst various carbon forms: 0D fullerene and quantum dots (carbon, graphene, graphene oxide), one-dimensional carbon nanotubes (single-walled and multi-walled), nanofibers and nanohorns, two-dimensional pristine graphene and its derivatives, and ordered mesoporous carbon have been used so far. With large size and higher dimensions as fillers, carbon nanoforms restrict the performance improvements of polymer membranes as it is hard to ensure their real incorporation inside membranes. One way is to meticulously control/reduce the size of nanofillers. With small sized carbon nanofillers the membrane antifouling resistance is enhanced. Further, OD carbon nanomaterials have proven promising for membrane technology due to their ultra-small size, rich chemical functional groups, and better antifouling properties. OD carbon nanoparticles result in a smoother membrane surface, smaller pore size, greater permeability enhancement in thin film nanocomposite (TFN) membranes, higher surface hydrophilicity and thus higher water flux composites. Therefore, here we report precisely on OD nano-forms of carbon materials in polymer membrane composites. Figure 2 is a schematic representation of carbon 0D forms. The crucial aspect of reviewing $0 \mathrm{D}$ carbon forms is that they have unique physical as well as surface properties, which help fabricate excellent carbon-incorporated polymer membranes based on a variety of polymers. Above all, the 0D carbon nano-forms are highly biocompatible, which is extremely vital for wastewater treatment, environmental sustainability and human health. In addition, with heaps of research carried out in the field of polymer membrane technology, the 0D carbon nanoforms embedded into polymers to form nanocomposite membranes are rarely reviewed. Therefore, we review the recent insights in the improvement and development of OD carbon-polymer nanocomposite membranes.

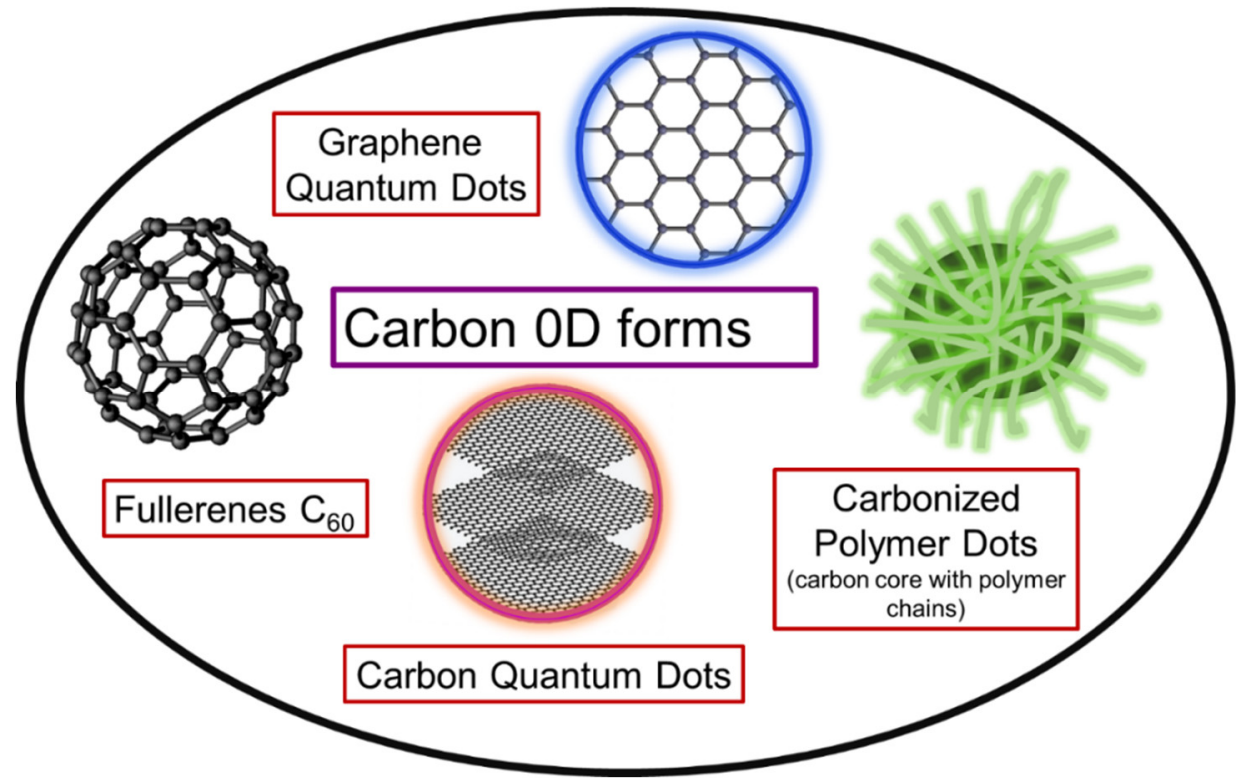

Figure 2. Schematic representation of carbon types in $0 \mathrm{D}$ form.

2. 0D carbon Nanomaterials (Fullerenes and Carbon Dots): Structure, Properties and Advantages

\subsection{Fullerenes}

Fullerenes are 0D nano-carbons that exist in closed-caged structure with pentagonal and hexagonal rings, represented with the formula of $C_{20+n}$ where $n$ is an integer. Spherical fullerene $\left(C_{60} /\right.$ buckyball $)$, is widely explored within entire fullerene family. It has the shape of an icosahedron, contains 12 pentagonal and 20 hexagonal rings, a perfect symmetrical cage structure, and is approximately $1 \mathrm{~nm}$ in size. Furthermore, carbon in $\mathrm{C}_{60}$ has sp $\mathrm{s}^{2}$ hybridization. $\mathrm{C}_{60}$ can resist high pressures (over $3000 \mathrm{~atm}$ pressure) and return to the original shape after the pressure is released. $C_{60}$ species have an effective 
bulk modulus of 668 GPa making it harder than diamond, a high refraction index, a dielectric constant $\sim 4$, a large molecular volume, high electron affinities, and large surface-to-volume ratios. $\mathrm{C}_{60}$ is traditionally produced by the arc-discharge method, chemical vapor deposition, or by combustion [30]. $\mathrm{C}_{60}$ is insoluble or sparingly soluble in several solvents like water. $\mathrm{C}_{60}$ dissolve in common solvents at room temperature. Toluene, benzene and carbon disulfide (organic solvents) are the solvents most often used to solubilize them. $\mathrm{C}_{60}$ is the only known allotrope of carbon with room temperature solubility, and this allows straightforward processing of $\mathrm{C}_{60}$ [31]. $\mathrm{C}_{60}$ contains carboxyl, epoxy, and hydroxyl surface groups capable of attracting water molecules. Their adsorption abilities to bond organic molecules through their covalent or non-covalent bonds are good, which facilitates functionalization. $\mathrm{C}_{60}$ has a spherical $\pi$-conjugated structure and the pyramidalization angle is large due to which chemical functionalization gets easier and higher solubility of $\mathrm{C}_{60}$ in many solvents is achieved. Furthermore, interactions of $\mathrm{C}_{60}$ with polymers are possible due to their molecular $\pi$-electron system which provides minimum transformations. $\mathrm{C}_{60}$ can be incorporated into a wide variety of polymers via formation of donor-acceptor or covalent bonds. By inclusion of $\mathrm{C}_{60}$ in the polymer matrix, the properties of the polymer changes comprehensively, although the unique properties of $\mathrm{C}_{60}$ are retained [32]. Figure 3 shows SEM micrographs illustrating the morphology of poly(phenylene-isophthalamide) membranes modified by 2,5 and $10 \mathrm{wt} \% \mathrm{C}_{60}$. The pristine membrane exhibits brittle fracture with a few fracture lines shown as sharp white lines and some plastic deformations shown as rounded white lines in image (a). Fracture surfaces with inclusion of $\mathrm{C}_{60}$ (images b-d) contains more plastic deformations, and there is an increase in the density with increasing $\mathrm{C}_{60}$ concentration. This shows that the polymer membrane matrix properties are strongly influenced by the carbon nanofiller. $\mathrm{C}_{60}$ has been tested by researchers for use in the environment and is found to be beneficial for water treatment. $\mathrm{C}_{60}$ s have a low aggregation tendency and a high surface area that makes their use as adsorbents in wastewater treatment plausible. $\mathrm{C}_{60}$ is preferred due to the low cost of production, easy operation and availability of different adsorbents. $\mathrm{C}_{60}$ is ideal as it can adsorb organic compounds in water and is much more effective than soot or activated carbon (a suitable adsorbent, which has a porous structure and large surface area). The ability of $\mathrm{C}_{60}$ to adsorb compounds is realized mainly through their interactions in dispersion solutions. Further, $\mathrm{C}_{60}$ is hydrophobic, has high electron affinity, large surface to volume ratio, more surface defects, low biological toxicity, and above all it is a photoactive molecule. $\mathrm{C}_{60}$ is hydrophobic in behavior and through functionalization it can be turned into a hydrophilic or amphiphilic substance $[33,34]$. Although beneficial for water treatment applications, the direct use of $\mathrm{C}_{60}$ in membrane development is challenging due to its low solubility and poor dispersibility [35]. And in most cases, it must be modified on its surface [8], or forms aggregated $\left(\mathrm{nC}_{60}\right)$ [9], or mixed with a suitable surfactant and stabilizing agents [10].

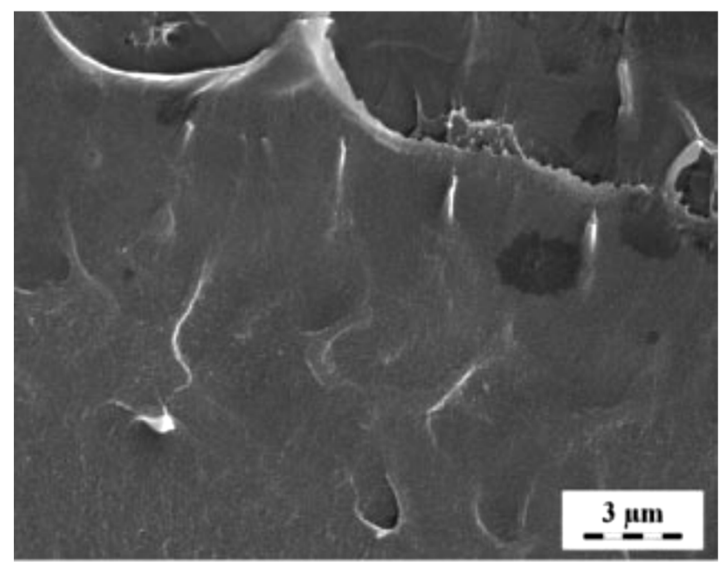

(a)

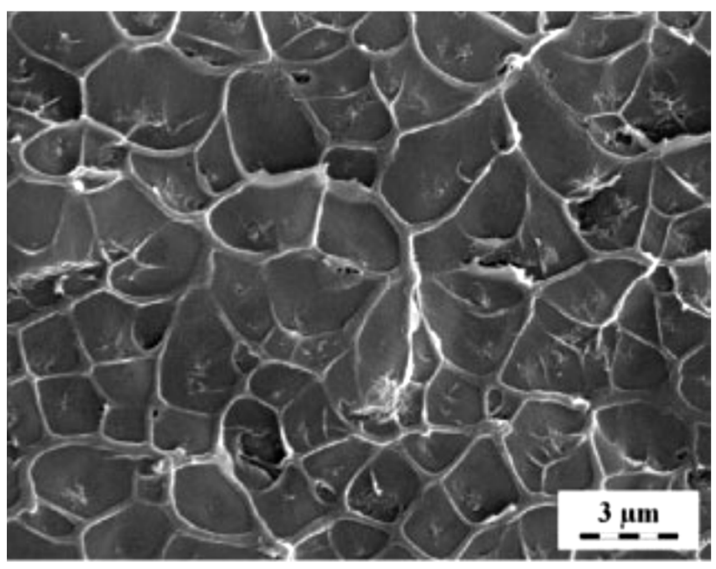

(b)

Figure 3. Cont. 


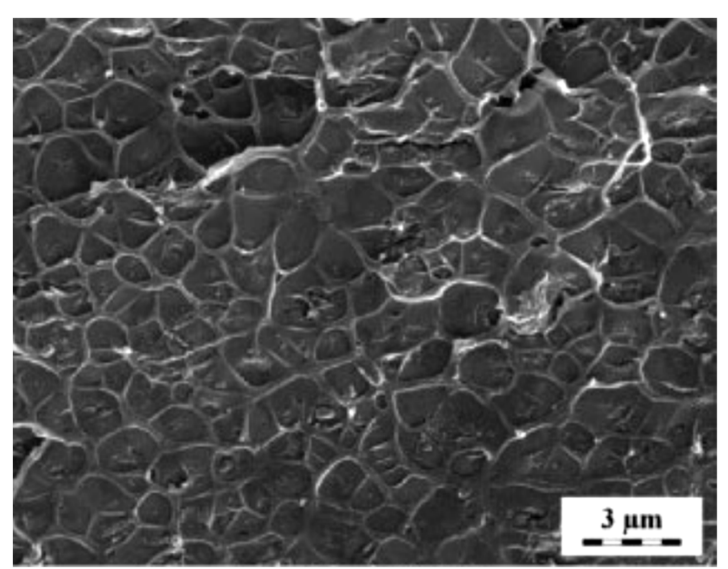

(c)

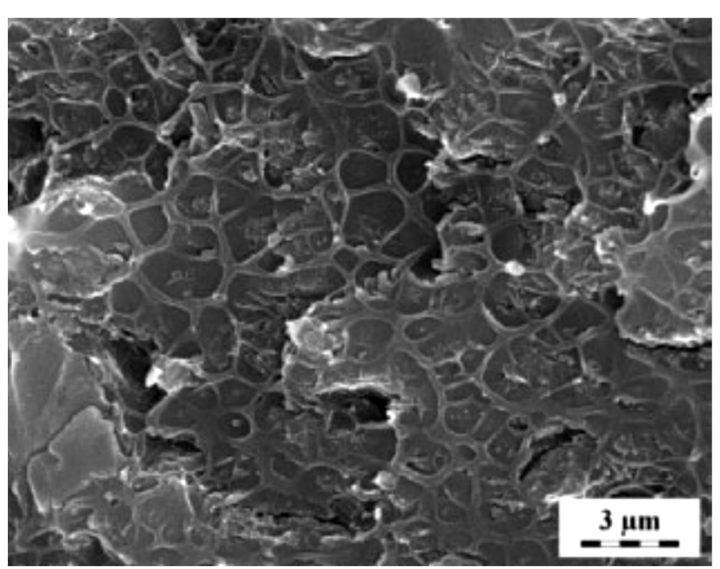

(d)

Figure 3. Polymer membrane SEM images representing the cross-sections of poly(phenyleneiso-phthalamide) without and with $2 \%, 5 \%$ and $10 \% \mathrm{C}_{60}$. Reproduced with permission from [32]. Copyright@ 2009 WILEY-VCH Verlag GmbH \& Co. KGaA, Weinheim, Germany. (a) Poly(phenyleneiso-phthalamide); (b) Poly(phenylene-iso-phthalamide) $+2 \% \mathrm{C}_{60}$; (c) Poly(phenylene-iso-phthalamide) $+5 \% \mathrm{C}_{60}$; (d) Poly(phenylene-iso-phthalamide) $+10 \% \mathrm{C}_{60}$.

\subsection{Carbon Dots}

Carbon dots (CDs) are 0D nano-carbon materials with sizes lower than $10 \mathrm{~nm}$, displaying bright fluorescence (the highest quantum yield over 90\%), with low toxicity and superior photostability [36]. CDs have intrinsic emission derived from the quantum confinement effect due to the existence of multiple photoluminescence centers. The observed photoluminescence is size independent, excitation dependent, has a broad emissive full width at half maxima and short lifetimes. CDs have superior optical properties such as strong absorption, bright photoluminescence, excellent light stability (resistance to light decomposition, photobleaching and blinking). Most CDs contain $\mathrm{sp}^{2}-\pi$ bonds, typically alike to nano crystalline graphite, although without structural identification [37-41]. Concretely they are classified as carbon nanodots (CnDs), carbon quantum dots (CQDs), graphene/graphene oxide quantum dots (GQDs/GoQDs), and carbonized polymer dots (CPDs). All of these types have similar sizes and photoelectrochemical properties, although they differ in carbon core structure, and surface chemical groups [42]. Amorphous quasi-spherical nanodots that lack quantum confinement are considered to be $\mathrm{CnDs}$. CnDs are mainly prepared by pyrolysis processes or by polymerization using tiny molecular precursors $[36,43,44]$. While spherical quantum dots with quantum confinement and crystalline structures are referred as CQDs, the optoelectronic properties of these quantum dots can be altered and enriched upon surface passivation or functionalization. The $\pi$-conjugated single graphene sheets are referred to as GQDs. By pyrolysis methods with graphite as starting material it is possible to exfoliate graphite into a few-layers of GQDs. GQDs must not be mistaken with CDs. The of core CDs is mainly composed of $\mathrm{sp}^{3}$-hybridized carbon, usually amorphous and spherical, with less than $10 \mathrm{~nm}$ in size. On the other hand, GQDs are a disk of graphene in the 2-20 nm size range and are composed mainly of $\mathrm{sp}^{2}$-hybridized carbon. They are crystalline and have "molecule-like" character rather than colloidal. Quantum confinement is still not well understood for GQDs. GQDs can have different sizes and the same bandgap energy (i.e., $3.4 \mathrm{eV}$ ), however, the bandgap energy of pristine graphene is $0 \mathrm{eV}$ or close to $0 \mathrm{eV}$, that's why they are named quantum dots when compared to graphene. Although GQDs have identical photoluminescence and similar emission properties to CDs. GQDs have molecule-like character and thus show tunable optoelectronic properties. The position of the absorption peak is not influenced by the size of GQDs, unlike other CDs. CDs and GQDs have complex surface functional groups, especially oxygen-related functional groups, such as carboxyl and hydroxyl. The surface groups contribute greatly to the optical properties of CDs and GQDs and even make them water-dispersible. CPDs have a mixed polymer-carbon structure and a 
carbon core. They comprise abundant functional groups and polymer chains on their surface. CPDs are obtained due to the incomplete carbonization of the polymer clusters while using the hydrothermal or solvothermal processes [45]. CPDs have prominent optical properties similar to CDs and GQDs, and in addition have the privilege of polymer properties such as abundant functional groups, short polymer chains and highly crosslinked network (polymer/carbon hybrid) structures. CPDs have excellent aqueous solubility and outstanding photoluminescence quantum yield as compared to CDs and GQDs. CPDs mostly possess strong blue and green emission, even up to several long wavelengths. They have strong absorption in the UV region and have excitation dependent emission. CPDs with dual-emission fluorescence intensities (red and blue emission) prepared in different $\mathrm{pH}$ conditions, were used to distinguish between four types of bacteria [46]. CPDs are newly emerging luminescent CDs and still lack use in membrane-based water treatment research.

CDs are mostly prepared using physical or chemical methods, denoted as "top-down" and "bottom-up" methods. With the development of microwave and hydrothermal technologies, various "bottom-up" methods were explored to prepare CDs from small molecules, graphite, polymers, biomolecules, and biomass [47-49]. Figure 4 is a schematic diagram which shows the formation of CDs from glycine and the formation includes dehydration, polymerization, carbonization and passivation steps [50]. CDs possess many functional groups on their surface which includes amines, epoxy, ethers, carbonyls, hydroxyls, and carboxylic acids [51]. Plenty of functional groups on the surface of CDs make them highly hydrophilic in nature and provide opportunities to functionalize them with a variety of organic, polymeric, inorganic, or biological species [26,52-55]. Since CDs are hydrophilic, they show good solubility and stability in water. CDs exhibit excellent biocompatibility, which can allow exposed cells or organisms to live sustainably, even at high concentrations [56-58]. In addition, CDs form high performance NF membranes and break the trade-off effect between water permeability and selectivity. Besides, GQDs have a strong sorption capacity for heavy metals compared to other substrates. The large amount of surface groups/polymer chains, such as carboxyl, hydroxyl, amine, etc., give rise to their excellent water solubility and convenience for forming composites with other materials without phase separation. TFNs with improved water permeability, antifouling performance, bactericidal effects or mono-/divalent ion separation capacity have been successfully developed. GoQDs-based composite membranes have favorable water permeability and are anticipated to be a creative filler to capture water molecules and provide shorter diffusion pathways in the membranes. Currently, the green synthesis (i.e., where the starting materials are non-toxic reagents, eco-friendly and biosafe) approach has gained a lot of popularity in the field of CQDs synthesis which has several advantages for the environment [57].

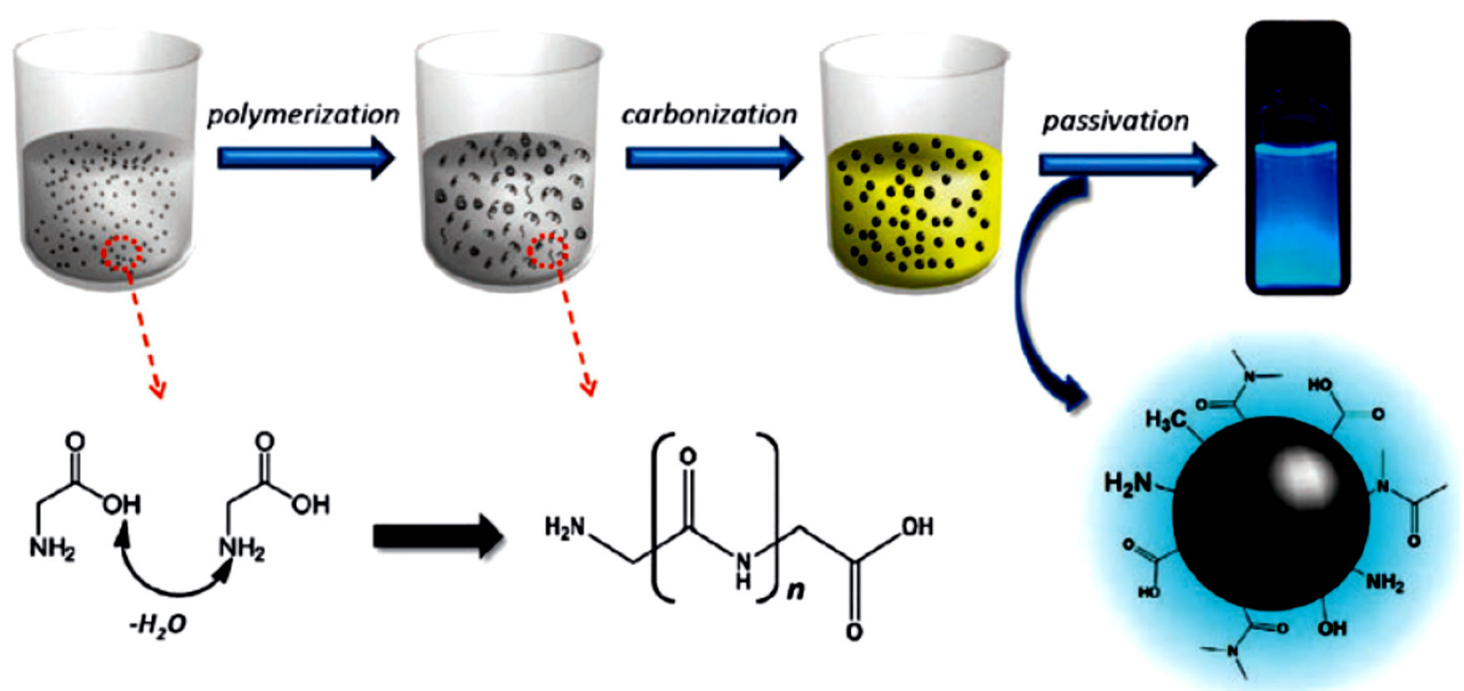

Figure 4. Synthesis of CDs from glycine showing dehydration, polymerization, carbonization and passivation. Reproduced with permission from [50]. Copyright ${ }^{\circledR}$ The Royal Society of Chemistry 2012. 


\section{Biocompatibility Implications of OD Nano-Carbon in Water Effluent Treatments}

During the process of wastewater treatment using carbon-polymer nanocomposite membranes, it is possible that the 0D nano-carbons might enter and remain in freshwater ecosystems. Thus, this section describes the study of their biocompatible impact. $\mathrm{C}_{60}$ is apt as a representative material for environmental studies. $\mathrm{C}_{60}$ is reported to be either not cytotoxic or harmful under specific conditions [59,60], and have biological consequences that are neutral [61-64]. The antibacterial activities of water-soluble $\mathrm{C}_{60}$ derivatives [65-67] or $\mathrm{nC}_{60}$ have been investigated, and the studies have shown that when $\mathrm{C}_{60}$ were prepared under specifically low salt conditions, they were found to be toxic to bacteria [68-70]. An anaerobic biodegradation of wastewater sludge was performed using $\mathrm{C}_{60}$. The analysis showed no significant effect on the structure or function of the anaerobic community [71]. For a basal soil respiration study, $1 \mu \mathrm{g}$ of $\mathrm{C}_{60}$ per gram of soil in aqueous suspension or $1000 \mu \mathrm{g}_{60}$ per gram of soil in granular form were used. From denaturing gradient gel electrophoresis profiles a slight impact on the structure (as shown in Figure 5) and on the function of the soil microbial community and processes was seen [72]. Furthermore, $\mathrm{C}_{60}$ is not cytotoxic towards human and animal cells in vitro although acute toxicity is observed in animal tissues in vivo [73-78]. By modifying the surface, the $\mathrm{C}_{60}$ can interact differently to the biological molecules and make them cytotoxic $[79,80]$. Thus, likely only modified $\mathrm{C}_{60}$ could be cytotoxic. $\mathrm{C}_{60} \mathrm{~s}$ are used as bio-receptors and sensors, as they are biocompatible with living organism-based nanomaterials [81-85]. Overall, $\mathrm{C}_{60}$ is non-toxic and can be safely exploited for water treatments such as filtration, as adsorbents, and membrane technologies for the environment.

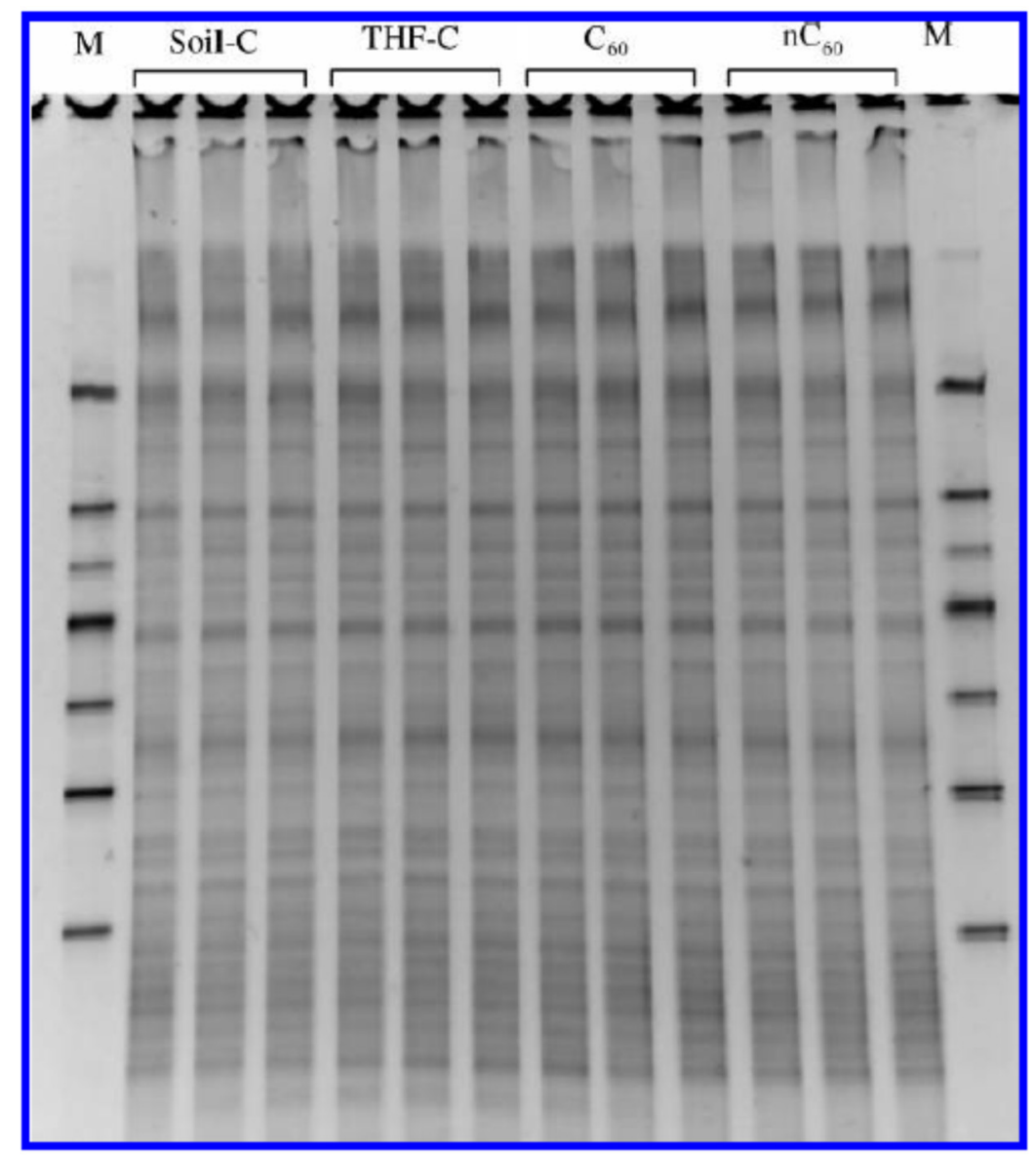

Figure 5. Denaturing gradient gel electrophoresis profiles of $16 \mathrm{~S}$ rRNA fragment amplified for three samples from the control soil and soils treated with tetrahydrofuran THF-C (control without carbon), $1 \mu \mathrm{g}$ of $\mathrm{C}_{60}$ per gram of soil in aqueous suspension and $1000 \mu \mathrm{g} \mathrm{C}_{60}$ per gram of soil in granular form after 180 days of incubation. $\mathrm{M}$ is the marker. Reproduced with permission from [72]. Copyright $(\mathrm{C}$ 2020, American Chemical Society. 
Few studies have examined the environmental behavior and toxicology of CDs on natural mineral particles [86-88]. Individual types of CDs possess distinct physicochemical properties, which in turn determine their potential toxicity. Generally, the carbon itself is not toxic and if any cytotoxicity is reported it is primarily due to the surface passivating agents used [89]. Even if CDs are modified with highly cytotoxic profile agents, they still can be used for in vivo applications, provided specific conditions are used such as low concentrations and short incubation times. CDs are safe for health and free of environmental concerns $[89,90]$ and have been developed for nanobioprobes and clinical treatments. CDs (with or without surface passivation) have low toxicity and can be internalized into cells for imaging purposes [91,92]. CDs have been demonstrated to cause no cytotoxicity at concentrations of approximately $0.1-10 \mu \mathrm{g} / \mathrm{mL}$ (which is $10-1000$ times higher than the normal amount required for imaging applications) [40]. The synthesis of CDs using green synthesis methods represents an improvement in biocompatibility and low cytotoxicity, which is crucial for the environment [57].

\section{Development and Influences of 0D Carbon Nano-Forms Incorporated in Various Polymers to Form Nanocomposite Membranes}

\subsection{Fullerene-Incorporated Polymer Nanocomposites}

$\mathrm{C}_{60}$ is often chemically functionalized so as to enhance the mixing capability of $\mathrm{C}_{60}$ with other host polymers $[93,94]$. A sequence of studies have shown that when the polymer membranes are modified with $\mathrm{C}_{60}$, the membranes' initial properties are improved [95]. The outstanding activity towards the damage by radicals, and excellent thermal as well as antifouling performance are reported. Usage of aromatic polyamides, such as polyphenylene isophthalamide shows promise for NF, UF, distillation, and reverse osmosis. These polymers are mechanically resistant, chemically stable, have low cost, ease of workability and rigidity, and have high porosity [96-99]. Novel membranes are made using aromatic polyamides, typically modified by polyhydroxylated $\mathrm{C}_{60}$ (fullerenol $\left./ \mathrm{C}_{60}(\mathrm{OH})_{n}\right)$, carboxy $\mathrm{C}_{60}$ and $\mathrm{C}_{60}$ derivatives with L-arginine via a solid phase synthesis route. These $\mathrm{C}_{60}$-modified polyamide membranes show high permeation fluxes and enhanced selectivity [100]. With the modification of aromatic polyamides by $\mathrm{C}_{60}$ derivatives, the structural environment of the polyamide changes (due to the noncovalent bonding between them) and the internal composite membrane structure changes. In addition, it is observed that the surface hydrophilicity, membrane density and surface roughness increases. Figure 6 shows the graphical form of mixed matrix pervaporation (PV) membranes prepared by Dimitrenko et al., and Table 1 shows the PV separation indexes. From Table 1 it can be seen that aromatic polyamide membranes modified with fullerenol shows the best transport properties for the PV of azeotropic methanol-toluene (72/28 wt\%) mixtures. In addition, in comparison to other $\mathrm{C}_{60}$ derivatives, membranes containing fullerenol show the highest permeation flux $\left(0.649 \mathrm{~kg} /\left(\mathrm{m}^{2} \mathrm{~h}\right)\right)$, and enhanced selectivity with respect to methanol. In another report, a polyphenylene isophthalamide membrane was modified by adding $10 \mathrm{wt} \% \mathrm{C}_{60}$ via a solid-phase method to form nano-UF membranes. With the increase in $\mathrm{C}_{60}$ content the membrane rigidity was enhanced and showed improvement in its technological parameters [96]. In addition, polyphenylene isophthalamide with $10 \mathrm{wt} \% \mathrm{C}_{60}$ membranes showed increased flux, reduced recovery (0.8-0.9) and lower protein sorption [101]. Polyphenylene isophthalamide with $\mathrm{C}_{60}$ improves the PV properties as well [32]. Furthermore, the physical properties of membranes such as the intrinsic viscosity are significantly influenced by the inclusion of $\mathrm{C}_{60}$ in a polyphenylene isophthalamide matrix. With the inclusion of $\mathrm{C}_{60}$, the structure of the membranes becomes more compact, denser, and reveals a non-monotonic effect on the glass transition temperature.

Asymmetric polymer membranes based on the hydrophobic polymer poly(2,6-dimethyl1,4-phenylene oxide) (PPO) with inclusion of 2 and $10 \mathrm{wt} \% \mathrm{C}_{60}$ are prepared using a solid-phase interaction method. These PPO-C 60 membranes are prepared to study removal and adsorption behaviors of estrogenic compounds. The morphology of the membranes showed an increase in the pore size and porosity on the dense top layer of PPO- $\mathrm{C}_{60}$ membranes as compared to pure PPO membrane. The permeation flux is reported to be higher for PPO- $10 \mathrm{wt} \% \mathrm{C}_{60}$ membranes. Notably, the effect on the inclusion of $\mathrm{C}_{60}$ in PPO matrix depends on the approach used for modifying the 
matrix [32]. Changes in the polymer properties after modification by $\mathrm{C}_{60}$ have been demonstrated using polymers such as poly(vinylpyrrolidone) (PVP) and polystyrene (PS) [102-104]. By spectroscopic analysis, it has been proven that donor-acceptor interactions exist between the polymers and $\mathrm{C}_{60}$ in PS- $\mathrm{C}_{60}$ [104] and PVP-C 60 [96] complexes. It is reported that membranes formed using fullerenol and PVP-C $_{60}$ are useful in water treatments as these membranes can help to target specific pollutants or microorganisms in the water, and are more sensitive to superoxide or singlet oxygen [105]. $C_{60}$ and $\mathrm{C}_{60}(\mathrm{OH})_{12}$-doped Nafion composite membranes were fabricated by Tasaki et al. through a solution casting method. This method opened the possibility to directly incorporate $\mathrm{C}_{60}$ into immiscible polymers without any chemical modification. By using this method, the characteristics of $\mathrm{C}_{60}$ and $\mathrm{C}_{60}(\mathrm{OH})_{12}$ were retained in the Nafion composite membranes [106]. Photoconductivity and antimicrobial activity studies have been performed using $\mathrm{C}_{60}$ incorporated into a variety of polymers such as polycarbonate, polyethylene, PS-polyisoprene-PS, PS-polybutadiene-PS, polythiophenes, poly(bromostyrene), poly(n-vinylcarbazole), and 1,4-polydiene [107-113].

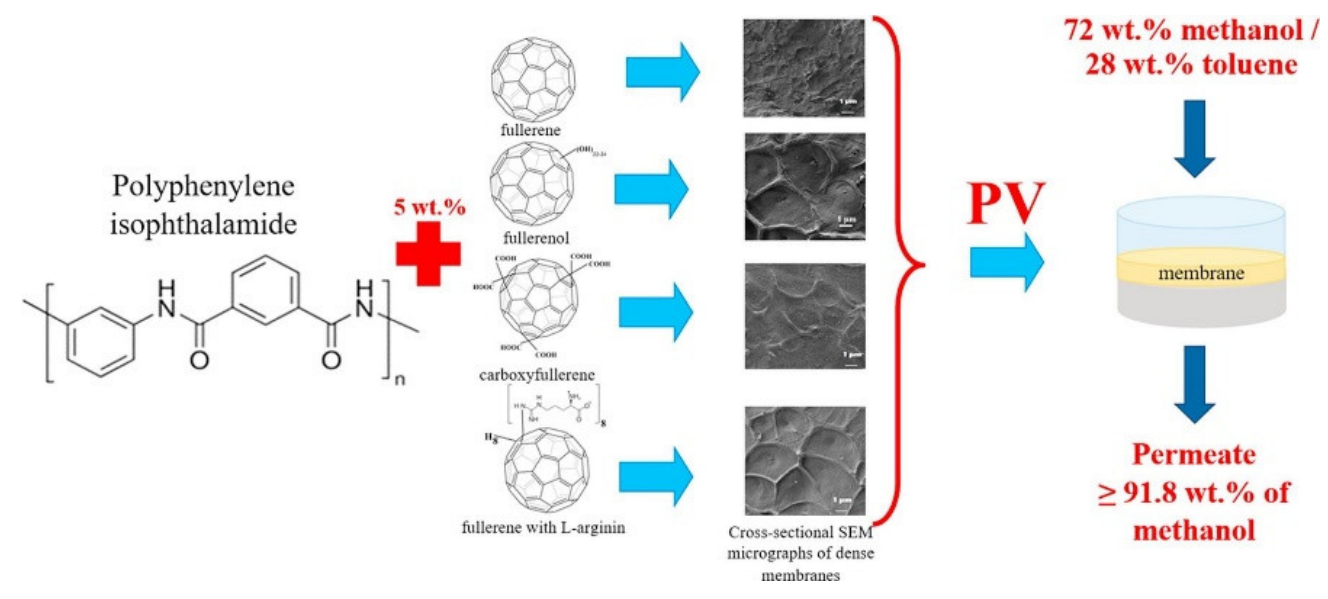

Figure 6. Graphical representation of development of novel polyphenylene isophthalamide PV membranes modified with various types of $\mathrm{C}_{60}$ derivatives and.

Table 1. It is the comparison of transport properties for the PV of azeotropic methanol-toluene $(72-28 \mathrm{wt} \%)$ mixture at $22{ }^{\circ} \mathrm{C}$. Reproduced with permission from [100]. Copyright@ 2020 Elsevier B.V.

\begin{tabular}{|c|c|c|c|c|c|c|}
\hline \multirow{2}{*}{ Membranes } & \multicolumn{3}{|c|}{$\begin{array}{c}\text { The Second Regime (PV of Only the Azeotropic } \\
\text { Methanol-Toluene Mixture) }\end{array}$} & \multicolumn{3}{|c|}{$\begin{array}{l}\text { The First Regime (PV of the Azeotropic } \\
\text { Methanol-Toluene Mixture in Series of } \\
\text { Experiments in a Wide Concentration Range) }\end{array}$} \\
\hline & $\begin{array}{l}\text { Permeation } \\
\text { Flux, } \\
\mathrm{kg} /\left(\mathrm{m}^{2} \mathrm{~h}\right)\end{array}$ & $\begin{array}{l}\text { Methanol } \\
\text { Content in the } \\
\text { Permeate, wt } \%\end{array}$ & $\begin{array}{l}\text { PV } \\
\text { Separation } \\
\text { Index }\end{array}$ & $\begin{array}{l}\text { Permeation } \\
\text { Flux, } \\
\mathrm{kg} /\left(\mathrm{m}^{2} \mathrm{~h}\right)\end{array}$ & $\begin{array}{l}\text { Methanol } \\
\text { Content in the } \\
\text { Permeate, wt } \%\end{array}$ & $\begin{array}{l}\text { PV } \\
\text { Separation } \\
\text { Index }\end{array}$ \\
\hline $\begin{array}{l}\text { polyphenylene } \\
\text { isophthalamide }\end{array}$ & 0.332 & 92.0 & 1.15 & 0.147 & 94.2 & 0.78 \\
\hline $\begin{array}{c}\text { polyphenylene } \\
\text { isophthalamide/ } \mathrm{C}_{60}\end{array}$ & 0.400 & 91.8 & 1.34 & 0.160 & 94.8 & 0.97 \\
\hline $\begin{array}{l}\text { polyphenylene } \\
\text { isophthalamide/carboxy } \mathrm{C}_{60}\end{array}$ & 0.492 & 93.1 & 2.09 & 0.179 & 97.7 & 2.78 \\
\hline $\begin{array}{l}\text { polyphenylene } \\
\text { isophthalamide/L-arginine }\end{array}$ & 0.552 & 92.2 & 1.99 & 0.191 & 95.7 & 1.46 \\
\hline $\begin{array}{c}\text { polyphenylene } \\
\text { isophthalamide/fullerenol }\end{array}$ & 0.649 & 92.1 & 2.25 & 0.214 & 95.9 & 1.73 \\
\hline
\end{tabular}

\subsection{Carbon Dot-Incorporated Polymer Nanocomposites}

CDs have plenty of hydrophilic carbonyl and carboxyl groups on their surface which benefits their uniform dispersion in water. In addition, these surface functional groups provide an immense tendency to get attached to the pendant polar groups that are present in polymers. Further, these functional groups help to ease the membrane fabrication process while incorporating CDs into polymers and provide better 
membrane performances [114-117]. The working span of polymer composite membranes gets affected due to stress dissipation, lack of reinforcement homogeneity and may suffer from thermal stability. In this context, CQDs act as distinct reinforcers by providing uniform-dispersion, selective transport sites for separation membranes and play a significant role in the remediation. Few other advantages of CDs are their carbon core, finite tuned size, good dispersion in organic/aqueous solvents [116] and ease of synthesis [118]. Overall, their nontoxic nature permits a high potential use of CDs for modifying polymer membrane properties for water treatment uses. For the fabrication of polymer nanocomposite membranes, the surface chemistry of CDs is tuned so as to accomplish better membrane stability and performance as reported in references $[114,115,119]$. Sun et al., tuned the CQDs with a variety of functional groups such as carboxyl, amino and sulfonic acids and incorporated them in a polyamide layer via IP and studied the properties of the resulting membranes. The membranes functionalized with sulfonic acid functional groups on CQDs were reported to have a permeate flux of $42.1 \mathrm{~L} / \mathrm{m}^{2} \mathrm{~h}$ and $\mathrm{Na}_{2} \mathrm{SO}_{4}$ rejection of $93.6 \%$, and was endowed with the best antifouling performance. These changes in the membrane properties were due to the formation of looser polyamide chemical structures and a largely negatively charged membrane surface due to the incorporated CQDs, whereas, the membranes functionalized with amino-modified surface functional groups on CQDs exhibited better retention properties and exhibited a less negatively charged membrane surface compared to the non-functionalized CQDs-polyamide composite membranes [117]. CD-based membranes for water treatment are formed by two main approaches. First is CDs incorporated into a thin polymer layer, known as TFN membranes, where typically CDs are dispersed in the aqueous phase and subsequently contribute in the IP process to form TFN membranes. TFN membranes are produced via techniques such as coating in addition to IP processes, although large-scale preparation is a challenge. Secondly, mixed matrix membranes are composed by adding CDs in polymer matrices to form homogenous solutions via various spinning methods. Here the challenges are the uniform dispersion of CDs and leaching [120]. Approaches such as coating of CDs on the top layer of membrane surface are also reported.

Polyamide TFN membrane made by IP techniques differ in characteristics (higher water flux, separation capability, $\mathrm{pH}$ tolerance) from the asymmetric membranes which are formed via phase inversion techniques. Here, it is worth mentioning that particles with larger size allow faster fouling of membranes [121]. Conversely, using ultra-small sized nanoparticles, such as CQDs allow one to significantly enhance the membrane antifouling resistance [122,123]. Li et al. incorporated CDs which are super hydrophilic and have quantum sizes of $6.8 \mathrm{~nm}$ into a polyamide layer. The incorporation of such CDs led to higher surface hydrophilicity and water flux for the formed membranes [116]. Bi et al., fabricated TFN membranes incorporated with $\sim 2 \mathrm{~nm}$ GQDs via IP of piperazine and trimesoyl chloride. The GQDs were added as aqueous additives into the membranes and poly(ether sulfone) was used as support membrane. Addition of small-sized GQDs efficiently tuned the surface roughness, membrane structure and hydrophilicity of the formed TFN membranes [122]. Figure 7 is a schematic representation of flow of water passing through the membrane channels at the interface between the GQDs and the polyamide layer. These membranes present excellent water permeation, due to a synergistic effect of the surface hydrophilic GQDs. Additionally the graph in Figure 7 shows the antifouling properties of the GQD-based polyamide membranes that are assessed through a dead-end filtration experiment. The foulants used were bovine serum albumin, humic acid and emulsified oil. The results showed that steady water fluxes under harsh fouling conditions could be achieved using GQD-polyamide TFN membranes. 


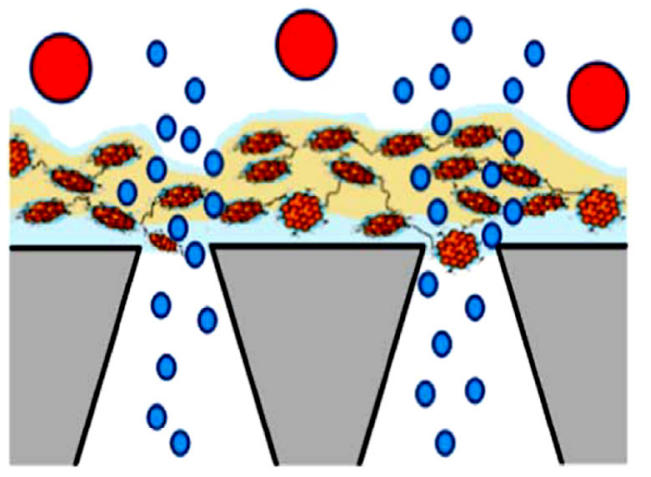

GQDs:

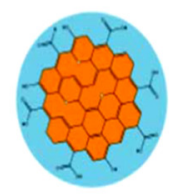

Water:

Dye:

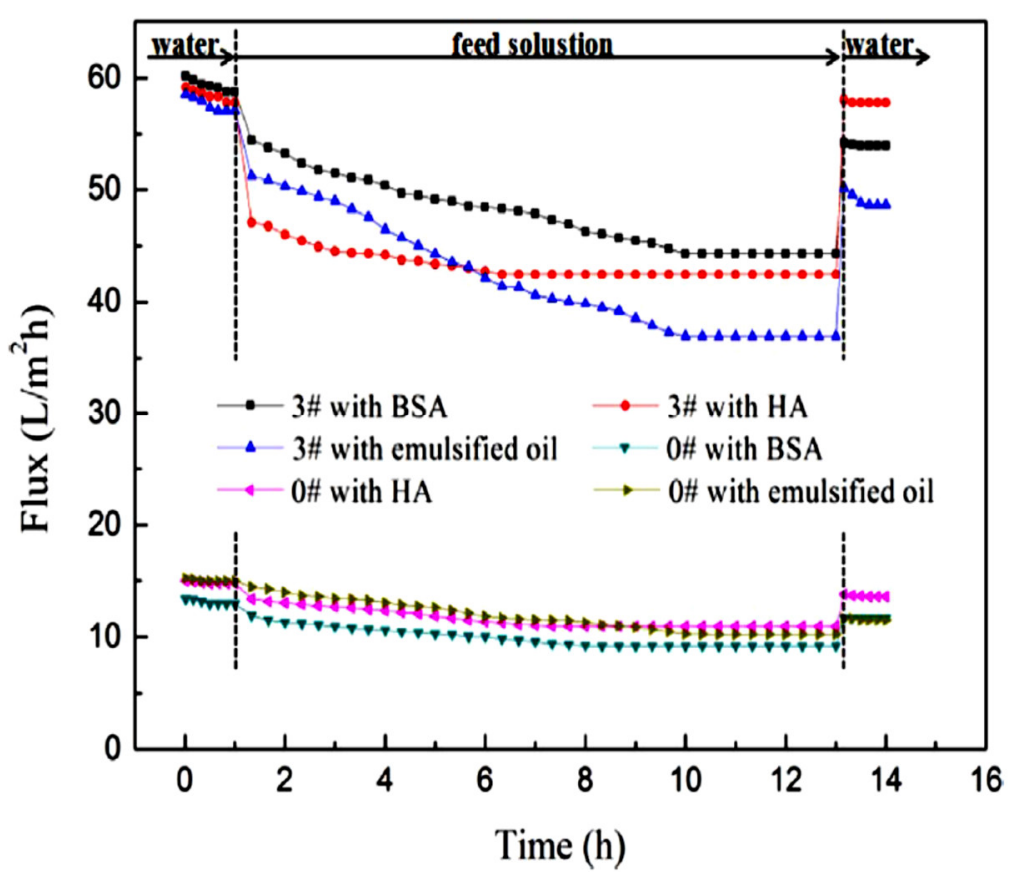

Figure 7. Schematic diagram of water channels in GQDs-polyamide TFN membranes. The graph shows the time-dependent flux of the prepared NF membrane (0\#) and the GQDs-polyamide TFN membrane (3\#) during the filtration of bovine serum albumin (BSA), humic acid (HA), and emulsified oil solutions. The experiments were carried out under operation pressure of $0.2 \mathrm{MPa}$. Reproduced with permission from [122]. Copyright (C 2020 Elsevier B.V.

Another report showed that nitrogen-doped GoQDs-polyamide TFN membranes could be developed. The formed amine groups on the GoQDs surface due to nitrogen doping were used as linkers to form chemical bonds between GoQDs and the polyamide matrix. The GoQDs formed stable dispersions, with improved thermal stability and surface hydrophilicity. Further, the water permeability increases thrice with maintained salt rejection, which is promising for high flux water desalination applications [119]. $\mu \mathrm{F}$ and UF membranes made from poly(vinylidene fluoride) (PVF), are widely used in industrial wastewater treatment, as the PVF membranes have superior chemical and thermal stability, high resistance to radiation and strong mechanical properties [124]. Zeng et al. used covalent bonding of GoQDs onto amino-modified PVF membranes, and found improved hydrophilicity, anti-bacterial, anti-fouling performance and an increase in water flux [125]. Moreover, the water contact angle was reported to decrease from $118.5^{\circ}$ to $34.3^{\circ}$ due to the coating of GoQDs on the PVF membrane surface. Novel GQDs-PVF nano-fibrous mixed matrix membranes are prepared for water desalination via an air gap membrane distillation process [126]. By adding GQDs the formed PVF membrane structure is more compact, has rougher surface and higher wetting resistance. CDs with tailored functional groups were facilely synthesized and embedded into polyethyleneimine matrix, and then dip-coated on polyacrylonitrile support to prepare composite membranes. The method 
used is IP, and these membranes are prepared to study polar organic solvent transport across the membranes for NF. The low and high carbonation degrees of CDs were obtained by decreasing glycerol mass in the reaction solution while modifying the surface of CDs. The low carbonation CDs could facilitate polar solvent migration through the membrane by providing bonding sites of hydrophilic groups $\left(-\mathrm{OH},-\mathrm{CO}_{2} \mathrm{H},-\mathrm{NH}_{2}\right)$. In contrast, high carbonation CDs showed an increase of non-polar solvent uptake and permeation via their hydrophobic domains [114]. Another report shows that the membrane hydrophilicity is improved by $\mathrm{Na}^{+}$functionalization on CQDs [127,128], as the existence of $\mathrm{Na}^{+}$containing groups facilitates uniform dispersion of CQDs in aqueous solutions. Moreover, $\mathrm{Na}^{+}$-containing CQDs exhibited the highest water flux of $53.54 \mathrm{~L} / \mathrm{m}^{2} \mathrm{~h}$ and power density of $34.20 \mathrm{~W} / \mathrm{m}^{2}$ for pressure retarded osmosis membranes [115]. The $\mathrm{Na}^{+}$functionalized on CQDs is dispersed during the IP in the polyamide selective layer to form novel TFC membranes, and the membranes showed effective changes in the surface structure of membranes due to their rich functionality and small size. The membranes were prepared to remove heavy metals via NF [128]. TFN membranes incorporated with GQDs embedded in a polyamide matrix via IP of piperazine and trimesoyl chloride were fabricated. The formed GQDs-polyamide TFN membranes exhibited enhanced water permeability and antifouling properties [122]. The amine groups of piperazine and hydroxyl or carboxyl groups of GQDs reacted with the acyl chloride groups of trimesoyl chloride at the oil/water phase zone during the IP method, which resulted in an ultrathin polyamide layer on the porous substrate. Nanocomposites consisting of CDs and polypyrrole, with high electrical conductivity exhibited high selectivity and sensitivity for the detection of trace amounts of picric acid that are present in water and soil [129]. Polyacrylonitrile-CQD composite nanofibers were produced by electrospinning and were characterized. And these composites could have possible future applications in wide areas of research such as smart clothing, high-performance aircrafts, sensors, photochemical reactions, biological imaging, and optoelectronic devices [130]. Most of the prepared polymer membranes based on 0D carbon forms are spherical dot-like, agglomerated or sheets and are in the form of TFC (with nanocomposite substrate) and TFN (with porous substrates or surface-coated TFC). Few researchers have prepared TFC on hollow fiber membranes. Efficient polymer membranes are prepared using nanofibrous GQDs. Reports show that by incorporating CDs the membranes form finger-like structural morphology with a smooth surface, and even porous fingerlike macrovoid structural membranes are reported using GoQDs sheets. $\mathrm{C}_{18}-\mathrm{CQDs}$ that have a knitted structure were used to prepare TFN membranes with a substrate composed of fibers. $\mathrm{C}_{60}(\mathrm{OH})_{24-28}$ with TFN showed a membrane surface with leaf-like structures. Precisely, incorporation of nano-sized CDs, irrespective of their shape, into the polymeric matrix to form membrane enhances the membrane properties which are mostly the mechanical strength and antifouling property.

\section{0D Carbon-Incorporated Polymer Nanocomposite Membranes for Wastewater Treatment}

Carbon-polymer nanocomposite membranes are prepared by incorporating various forms of nano-carbon (filler) into a polymer matrix [131,132]. The carbon-polymer nanocomposite membranes are used in broad application areas for desalination, antibacterial applications, and removing inorganic contaminants, dyes, natural organic matter, separation of nano-matter, water flux oil rejection, and emerging contaminants of concern. Mainly, these OD carbon nano-forms incorporated into polymer matrices have demonstrated immense capability and potential for eliminating various water pollutants such as pathogens, heavy-metal ions, and recalcitrant organic compounds [133-135]. Thereby, desired efficient water-treatment technologies such as 0D carbon-polymer nanocomposite membranes can act as supplements or substitutes for the traditional ones in the future.

\subsection{Fullerene-Based Polymer-Nanocomposite Membranes}

In studies by Brunet et al. hydrophilic functionalized $\mathrm{C}_{60}$ species were prepared and by utilizing the photocatalytic property of $\mathrm{C}_{60}$ they could be used to kill pathogenic microorganisms that are present in water [105], thus showing the benefits of $C_{60}$ for water treatment. Further, sorption is one of the methods to get rid of heavy metals such as cadmium, lead, zinc, nickel, cobalt, copper, arsenic, 
and mercury, etc., from wastewater effluents. The sorption capacity of metals is usually associated with surface defects and the lattice structure of the material used [136,137]. Conventional materials have low metal sorption capacity and low metal removal efficiency while treating wastewater. By using $C_{60}$, a porous structure was developed with an increase in the hydrophobicity of the prepared adsorbents and the results showed an improvement in metal sorption capacity. For instance, using $0.001-0.004 \%$ of the $\mathrm{C}_{60}$ in activated carbon, the sorption capacity for heavy metals such as lead (II) and copper (II) increased by 1.5-2.5 times [138]. Additionally the electronic properties of $\mathrm{C}_{60}$-based composite materials could be utilized as they have been reported to show higher specific capacitance of $135.36 \mathrm{Fg}^{-1}$, and better retention time [139]. Alekseeva et al. reported that a $\mathrm{C}_{60}$-based nanocomposite-PS film which had better efficiency for the removal of $\mathrm{Cu}^{2+}$ ions, following a Langmuir model [140]. The fabrication of $\mathrm{C}_{60}$-based polymer film increases its hydrophobicity, which makes them better in adsorption and easier in recycling [141]. Asymmetric UF membranes based on poly(phenylene isophtalamide)- $\mathrm{C}_{60}$ composite membranes were prepared by a phase inversion technique [96]. The phosphate buffer flux reduced recovery was estimated by static sorption tests. For the static sorption tests, the membranes were immersed in a protein solution for $20 \mathrm{~h}$. The results showed that with an increase in $\mathrm{C}_{60}$ content, the protein adsorption decreases on the membrane surface and shows better values of flux reduced recovery rates. Dmitrenko et al., studied the transport properties of dense polyphenylene isophthalamide membranes modified by $\mathrm{C}_{60}$ and its derivatives, and tested the PV separation of methanol/toluene mixtures, including azeotropic compositions [100]. The results showed an improved permeation flux of $0.084-0.214 \mathrm{~kg} /\left(\mathrm{m}^{2} \mathrm{~h}\right)$ and a high level of selectivity. Antibacterial membranes prepared by grafting $\mathrm{C}_{60}$ with PVP showing the safety of using $\mathrm{C}_{60}$ have been reported for water disinfection. $\mathrm{C}_{60} \mathrm{~s}$ act as nano-adsorbents in the membranes and improve the membranes' adsorption efficiency. Hydrophobic PPO membranes incorporated with various compositions of $\mathrm{C}_{60}$ were studied for removal and adsorption behaviors of the natural hormone estrone. The results showed the importance of membrane pore size and internal structure [142]. $\mathrm{C}_{60}$ incorporation in hydrophobic polymers improved 8-fold the permeate flux compared to pristine polymer membranes. For long term filtration, $10 \mathrm{wt} \% \mathrm{C}_{60}$-PPO nanocomposite membranes showed good removal performance of at least $95 \%$ of permeate, attributed to $\mathrm{C}_{60}$ 's adsorption capabilities and steric hindrance effects. Plisko et al. fabricated novel polyamide- $\mathrm{C}_{60}(\mathrm{OH})_{22-24}$ TFN hollow fiber membranes [143]. $\mathrm{C}_{60}(\mathrm{OH})_{22-24}$ was incorporated via an aqueous phase in triethylenetetramine onto the polysulfone substrate during IP. The TFN membrane containing $0.5 \mathrm{wt} \%$ of $\mathrm{C}_{60}(\mathrm{OH})_{22-24}$ demonstrated the best antifouling performance for removal of the organic matter. Perera et al. fabricated $\mathrm{C}_{60}(\mathrm{OH})_{24-28}$ incorporated TFC membranes for forward osmosis by IP process, showing improved specific desalination performances [144]. Superior desalination performances such as water flux, reverse salt flux, antifouling propensity, water permeability and salt permeability of the fabricated $\mathrm{C}_{60}(\mathrm{OH})_{24-28}$ based TFN membranes were presented. Introduction of various $\mathrm{C}_{60}(\mathrm{OH})_{24-28}$ loading on the polyamide topmost surface yielded an increase of pure water flux, decreased salt rejection, and superior antifouling performance. With a loading of 400 ppm $\mathrm{C}_{60}(\mathrm{OH})_{24-28}$, a water flux of $26.1 \mathrm{~L} / \mathrm{m}^{2} \mathrm{~h}$, higher than that of the pure TFC membrane was reported. Shen et al. developed a novel TFN membrane by loading fullerenol via IP. With $0.01 \%$ $(\mathrm{w} / \mathrm{v})$ fullerenol, the membrane revealed excellent antifouling ability, stable and high efficiency in $\mathrm{Mg}^{2+} / \mathrm{Li}^{+}$separation with a high separation factor of 13.1. These membranes formed were suggested to have great potential in the recovery of $\mathrm{Li}^{+}$from seawater [145]. Liu et al. reported $\mathrm{C}_{60}$ grafted graphene oxide membranes with a fixed interlayer spacing around $\sim 12.5 \AA$ [146]. Figure 8 shows the fabrication process, the water desalination setup and the schematic representation of blockage of anions and cations through the membrane. The membranes were reported to obtain a high water flux up to $10.85 \mathrm{~L} / \mathrm{m}^{2} \mathrm{hbar}$ (which is high enough for brackish water desalination), and $0.1883 \mathrm{~mol} / \mathrm{m}^{2} \mathrm{hbar}$ ion permeation rate at an applied pressure of 5 bar. Although $\mathrm{C}_{60}$ has great potential for water adsorption application, the cost of production into large quantities is high, which restricts their convenience in utilization. Thus, there are very few reports on $\mathrm{C}_{60}$ for wastewater treatments so far. 

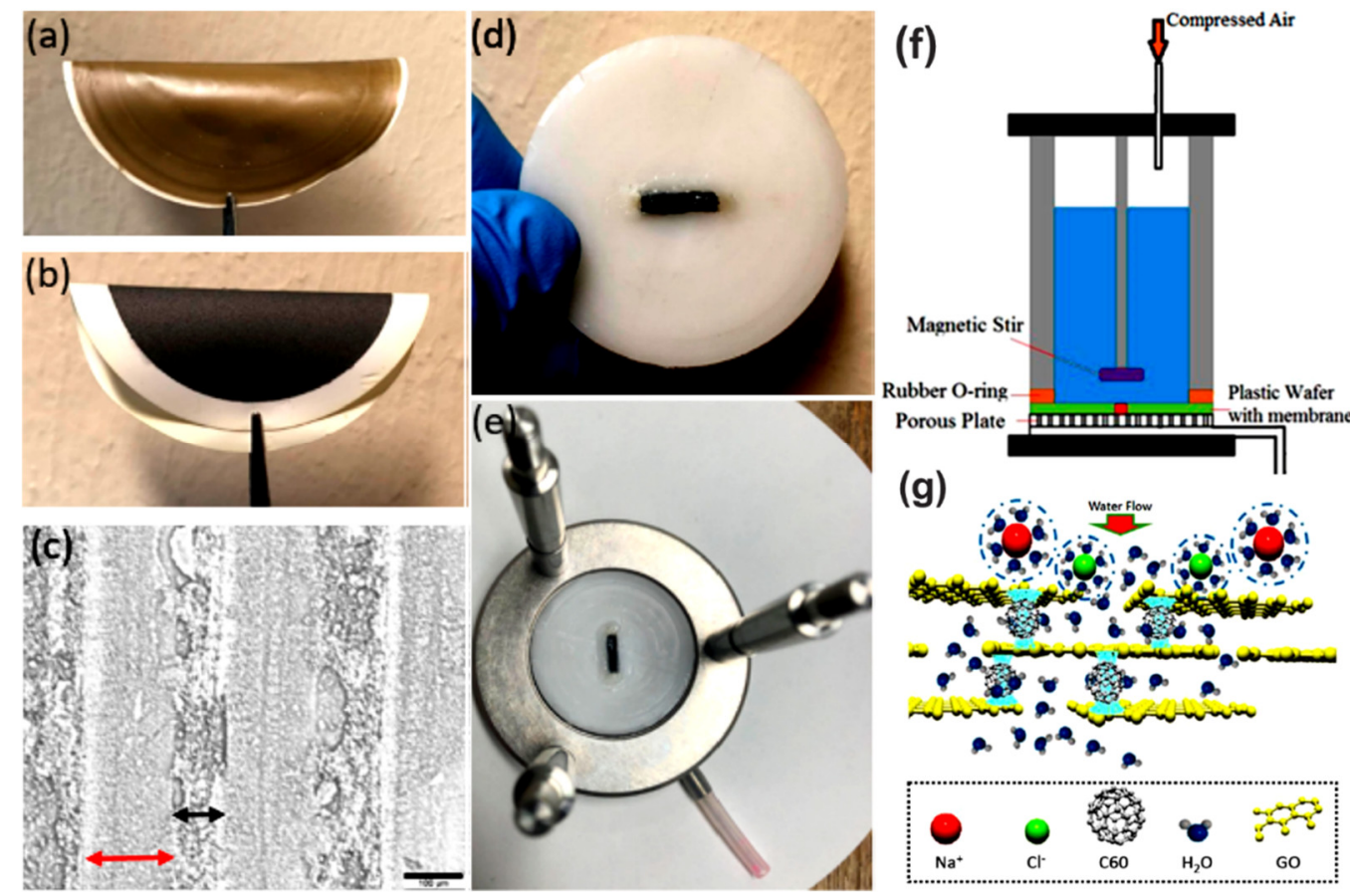

Figure 8. Fabrication process and water desalination setup using $\mathrm{C}_{60}$ grafted graphene oxide membranes. The photograph shows (a) graphene oxide membrane without $\mathrm{C}_{60}$, (b) $\mathrm{C}_{60}$ grafted graphene oxide membrane, (c) is the optical micrograph of the cross-sectional area with scale bar $100 \mu \mathrm{m}$. The micrograph shows $148 \mu \mathrm{m}$ thick graphene oxide laminates (red arrow) embedded in $81 \mu \mathrm{m}$ thick epoxy (black arrow). Epoxy and graphene oxide- $\mathrm{C}_{60}$ layers are labeled in the figure. (d) graphene oxide- $\mathrm{C}_{60}$ membrane encapsulated with epoxy and glued into a rectangular slot within a plastic disk of $47 \mathrm{~mm}$ in diameter, (e) graphene oxide- $\mathrm{C}_{60}$ membrane inside the water desalination setup, (f) and (g) are schematic setup of flat membrane made of graphene oxide and $\mathrm{C}_{60}$ hybrid for water desalination. $\mathrm{C}_{60}$ was grafted between the laminates of graphene oxide. The pressure is applied from the top and when the water passes through the membrane the anion and cation are blocked. Reproduced with permission from [146]. Copyright(C) 2020, American Chemical Society.

\subsection{Carbon Dot-Based Polymer-Nanocomposite Membranes}

CDs can be used as adsorbents to remove contaminants from wastewater [147]. Wang et al., reported the formation of periodic mesoporous organosilica embedded with CDs and adopted them as an adsorbent for the removal of toxic organic pollutants (2,4-dichlorophenol) and inorganic metal ions (mercury (II), copper (II) and lead (II)). The adsorptions followed Langmuir and Freundlich models and obeyed pseudo-second-order kinetics [147]. CQDs have high-performance efficiency in water treatment membranes as they are hydrophilic by excellence, have desirable size, tunable surface functional properties, and favorable polymer affinity. It is shown that the separation performance of the CQD-based polymer membranes can be effectively modulated by tuning the functional groups on the surface of CQDs [117]. A $5 \mathrm{~nm}$ CQD with tunable functional surface groups i.e., low and high carbonation degree, was easily synthesized and embedded into a polyethyleneimine matrix, and then dip-coated on a polyacrylonitrile support to prepare composite membranes. The prepared CQD-based NF membranes were fabricated for separation of organic solvents. Solvent resistance, solvent flux, and solute rejection were evaluated. It was observed that low carbonated CQD slightly suppresses the uptake and permeation for non-polar solvents. Conversely it enhances permeation for polar solvents. The membranes which were prepared with highly carbonated CQD acting as a non-polar solvent accelerator through their hydrophobic domains, and shows that the permeation of polar solvents is blocked [114]. CQD-based NF membranes have been proven efficient for biogas slurry valorization to reduce the environmental pollution [148]. The membranes prepared for biogas 
slurry valorization consisted of hydrophilic CQDs interlayered between the substrate and selective TFC NF membrane layers. CQDs as interlayers resulted in an enhanced water permeation of the NF membranes as they provided channels for fast water and ion transport, thus demonstrating a fantastic separation performance. CQDs as excellent membrane modifier for the desalination and wastewater treatment have been reported by Koulivand et al. [149]. For modifying the membrane properties, CQDs were synthesized by a pyrolysis method and were added to the polyether sulfone casting solution using a non-solvent induced phase inversion technique. Addition of CQD into the polyether sulfone membrane matrix, resulted in improved membrane morphology, porosity, surface charge, permeability $\left(76.5 \mathrm{~kg} / \mathrm{m}^{2} \mathrm{~h}\right)$, and enhanced fouling resistance of the membrane. The fouling resistance was enhanced due to the decreased water contact angle and increasing surface hydrophilicity provided by the incorporation of CQDs. In addition, separation tests of reactive red 198 dye and salts $\left(\mathrm{Na}_{2} \mathrm{SO}_{4}, \mathrm{MgSO}_{4}\right.$, and $\left.\mathrm{NaCl}\right)$ showed higher retention performance due to the presence of CQDs in membranes. Super hydrophilic $6.8 \mathrm{~nm}$ CQDs $(0.02 \mathrm{wt} \%)$ were incorporated into the selective layer of polyamide TFN reverse osmosis membrane [116]. The CQD-polyamide TFN membrane exhibited promising desalination performance with a water flux of $87.1 \mathrm{~L} / \mathrm{m}^{2} \mathrm{~h}$, salt rejection of $98.8 \%$ for long durations. Zhao and co-workers reported $3.2 \mathrm{~nm}$-sized CQDs immobilized onto the polydopamine layer which is grafted on the surface of poly(ether sulfone) substrate were prepared for pressure retarded osmotic power generation and waste water treatments. Due to the immobilization of CQDs, the membranes possessed high power density, enhanced antibacterial and anti-biofouling activity [32]. $\mathrm{Na}^{+}$functionalized CQDs have been preferred in the forward osmosis membranes as it is reported that the presence of CQDs draw solutes and attain the highest water flux for seawater desalination [127]. A comparative study was carried by Gai et al. where three kinds of CQDs (i.e., original, $\mathrm{Na}^{+}$functionalized at $\mathrm{pH} 5$ and $\mathrm{pH}$ 9) were synthesized and then embedded into polyamide layers as pressure-retarded osmosis membranes [115]. It was demonstrated that the $\mathrm{Na}^{+}$functionalized CQDs with $\mathrm{pH} 9$ exhibited the highest water flux of $53.54 \mathrm{~L} / \mathrm{m}^{2} \mathrm{~h}$ and a power density of $34.20 \mathrm{~W} / \mathrm{m}^{2}$. $\mathrm{Na}^{+}$functionalized CQD nanofillers were used to develop TFN hollow fiber membranes via IP for brackish water desalination. Water and salt permeability, water flux and solute rejection using the prepared membranes were carried out. The water flux and salt rejection were increased to $53.54 \mathrm{~L} / \mathrm{m}^{2} \mathrm{~h}$ and $98.6 \%$ with the loading of $\mathrm{Na}^{+}$functionalized CQDs as nanofillers. Although precise measures to design of a polymer-CQD nanocomposite are lacking, it may reveal a huge potential in water treatments [150]. Moreover, He et al. reported the influence of $\mathrm{Na}^{+}$modified on CQDs for the formation of polyamide TFN membranes. The surface structure and hydrophilicity of the formed TFN membrane were improved due to the uniform dispersion of CQDs possible due to $\mathrm{Na}^{+}$functionalization [128]. The influence of $\mathrm{Na}^{+}$modified on CQDs $(0.05 \mathrm{wt} \%)$ showed water permeability of $10.4 \mathrm{~L} / \mathrm{m}^{2} \mathrm{hbar}$ and impressive rejections of $97.5 \%, 98.2 \%$, and $99.5 \%$ towards $\mathrm{SeO}_{3}{ }^{2-}, \mathrm{SeO}_{4}{ }^{2-}$ and $\mathrm{HAsO}_{4}{ }^{2-}$, with a superior antifouling property and robust long-term stability. The formed membranes due to functionalization of $\mathrm{Na}^{+}$are anticipated to show improved separation performances of selenium and arsenate ion contaminations in surface and ground water. Lei et al. functionalized superior hydrophobic $\mathrm{C}_{18}$-CQDs by grafting CQDs with octadecylamine [151]. Superior hydrophobicity was achieved by cross-linking $\mathrm{C}_{18}$-CQDs with cotton textile using tolylene-2,4-diisocyanate. These hydrophobic $\mathrm{C}_{18}$-CQDs membranes were prepared for the separation of oil-water (99\%) and exhibited unique selectivity, feasible for water desalination. Owing to the photocatalytic properties of CQDs, NF CQDs-polydopamine membranes are fabricated as durable self-cleaning membranes (the fabrication process is shown in Figure 9) [152]. The insertion of the polydopamine-photoactive CQDs sandwich can degrade organic molecules adsorbed on the surface of the membrane under visible light, and show it is promising for low-cost fouling remediation and for self-cleaning. 


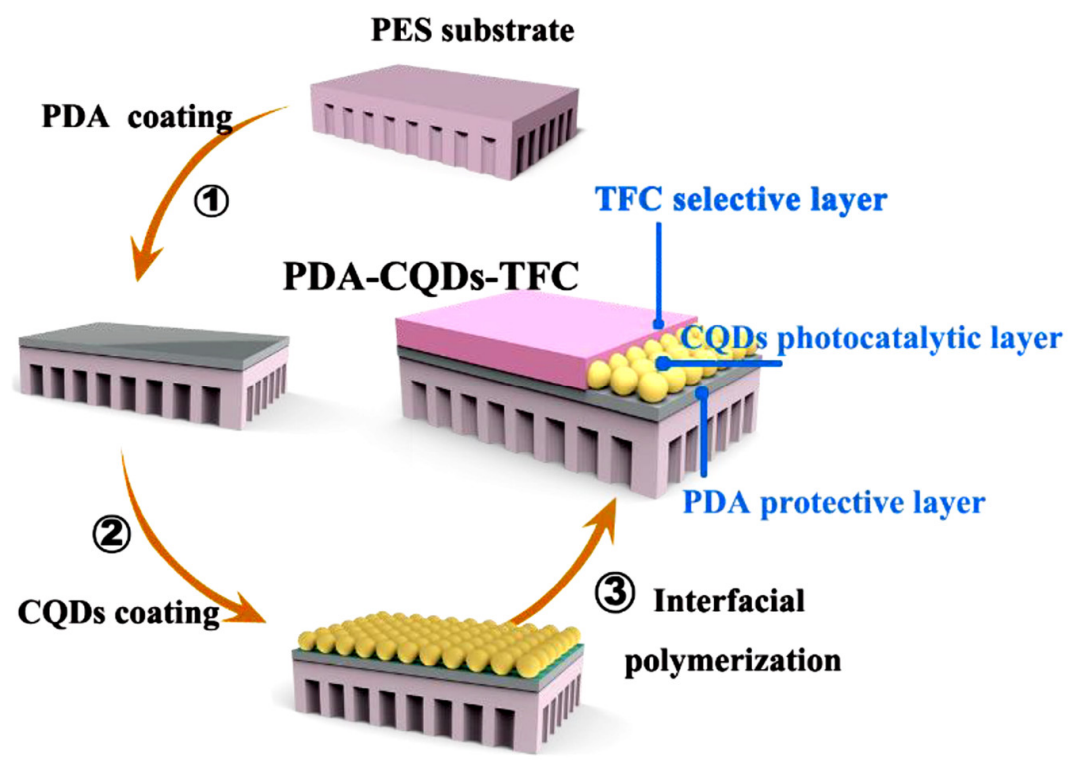

Figure 9. Preparation process of a self-cleaning NF membrane. In the figure PDA stands for polydopamine and PES is polyethersulfone. Reproduced with permission from [152]. Copyright (C) 2020, American Chemical Society.

Punrat et al. prepared polyaniline-GQD nanocomposite membranes to assess $\mathrm{Cr}$ (VI) levels in mineral drinking water and in deteriorated Cr-plating samples. The recovery rate was 80.3-106\% [153]. Bi et al. [122] prepared GQDs-polyamide TFN-NF membranes which are reported to have a maximal water permeance of $510 \mathrm{~L} / \mathrm{m}^{2} \mathrm{hMPa}$. This water permeance is nearly 6.8 times higher than that of the pristine polyamide membrane and it has good antifouling performance. In another report, Bi et al. [154] reported a GQDs incorporated in NF membranes that exhibited an ultrafast water permeance of $244.7 \mathrm{~L} / \mathrm{m}^{2} \mathrm{hbar}$, about 5-6 times higher compared to previous reports, with a rejection of $92.9 \%$ and 98.8\% for Alcian blue and Congo red. Wu et al. fabricated a GQDs-based solvent resistant NF membrane via IP on hydrolyzed polyacrylonitrile support and the acetonitrile and hexane permeances reached 469 and $508 \mathrm{~L} / \mathrm{m} /{ }^{2} \mathrm{hMPa}$, respectively [155]. Li et al. [156] prepared GQDs-polyimide TFN membranes with improved solvent resistance and achieved higher ethanol permeances. The membranes had a sandwich-like structure using low concentrations of $\mathrm{m}$-phenylenediamine and trimesoyl chloride during IP. Due to the incorporation of GQDs the membrane thickness (about $25 \mathrm{~nm}$ ) was reduced and exhibited ultra-low surface roughness (average less than $2 \mathrm{~nm}$ ) Further, the GQDs incorporated membranes showed an increased Rhodamine B rejection (from $87.4 \%$ to $98.7 \%$ ) and an increased ethanol permeance (from 33.5 to $40.3 \mathrm{~L} / \mathrm{m}^{2} \mathrm{~h} \mathrm{MPa}{ }^{-1}$ ). In addition, the prepared membranes have superior solvent resistance, antifouling properties for long durations. GQDs functionalized with amino groups to form TFN membranes for solvent resistant NF membranes are reported [157]. The membranes exhibited excellent solvent resistance in strong polar solvents at high temperatures. Seyedpour et al. [158] incorporated nano-sized bactericidal GQDs in the active layer of forward osmosis membranes. The membranes' antimicrobial activity was improved and better forward osmosis performance was achieved. Xu et al., reported GQD-polyethyleneimine TFC membranes for forward osmosis desalination [159]. The covalent bonds formed between GQDs and polyethyleneimine helped to improve the stability of the membranes during filtration and hydraulic cleaning processes. The membrane loaded with $0.050 \mathrm{wt} \%$ GQDs had a hydrophilic and neutrally charged membrane surface, exhibiting enhanced water flux of $12.9 \mathrm{~L} / \mathrm{m}^{2} \mathrm{~h}$, and good anti-fouling performances. Thus, GQDs-based polymer nanocomposite membranes present great potential in applications such as desalination, purification and wastewater treatments.

Further, GoQDs have a particular size, shape, and edge structure and an excellent dispersion into the polymer matrix, which is desirable for separation and permeation applications, although few reports 
exist for water purification membranes using GoQDs. Song et al. were the first to incorporate GoQDs as nanofillers to form TFN reverse osmosis membranes. The membranes showed improved antifouling and chlorine resistance for desalination and water reclamation applications [160]. Fathizadeh et al. [119] fabricated nitrogen-doped GoQDs polyamide TFN membranes via IP. The membranes' water permeance was 2-fold more than that of the membranes without GoQDs with 93\% salt rejection. Zeng et al. reported covalently bonded GoQDs onto amino-modified polyvinylidene fluoride TFN membranes. Due to the unique structure and uniform dispersion of GoQDs in the membranes, the UF membranes had enhanced bactericidal, anti-biofouling performances, long-term stability and durability [125]. The water flux permeation increased from around $500 \mathrm{~L} / \mathrm{m}^{2} \mathrm{hbar}$ to $>3800 \mathrm{~L} / \mathrm{m}^{2} \mathrm{hbar}$. The membrane's hydrophilicity was improved with a decrease in water contact angle. Zhang et al., fabricated a low-pressure GoQDs based tannic acid film TFN NF membrane by IP [161]. The Congo red and methylene blue rejections were $99.8 \%$ and $97.6 \%$, with a water flux of $23.33 \mathrm{~L} / \mathrm{m}^{2} \mathrm{~h}$, due to the improved hydrophilicity, smooth, and negatively charged surface of the formed membranes. Nitrogen-doped GoQDs (0.02 wt\%)-based polyamide TFN membranes were prepared which showed a drastic change in the water flux, with preserved high salt rejection due to a superior thermal stability, improved hydrophilicity, and a higher effective surface area [119]. GoQDs have been integrated into poly(vinyl alcohol) and evenly cast on a polysulfone support membrane for PV. By integrating GOQDs on the membrane, the separation performance was changed with excellent dehydration of alcohol/water mixtures [162].

In Table 2, the average quantum size of all the 0D carbon nanofillers mentioned above used in polymer membrane technology is in the range between $1 \mathrm{~nm}$ to $20 \mathrm{~nm}$. When the nanofillers are functionalized or surface-modified, the size of the $0 \mathrm{D}$ carbon forms increases. The resulting membrane pore size or thickness changes and is dependent on the concentration of the nanofillers. For a particular case, blockage of the pores due to the presence of nanocarbons is also mentioned. From Table 2, a comparative study shows that the permeation flux is higher when using GQDs and GoQDs as nanofillers in polymer nanocomposite membranes and the solvent rejection is on average mostly above $90 \%$ for all kinds of nanocomposite 0D carbon fillers.

Table 2. Various types of OD carbon fillers used for water purification. The table includes the quantum sizes of nanofillers. And after incorporation of nano-carbon in polymer membranes, their resultant membrane pore sizes and their permeation fluxes.

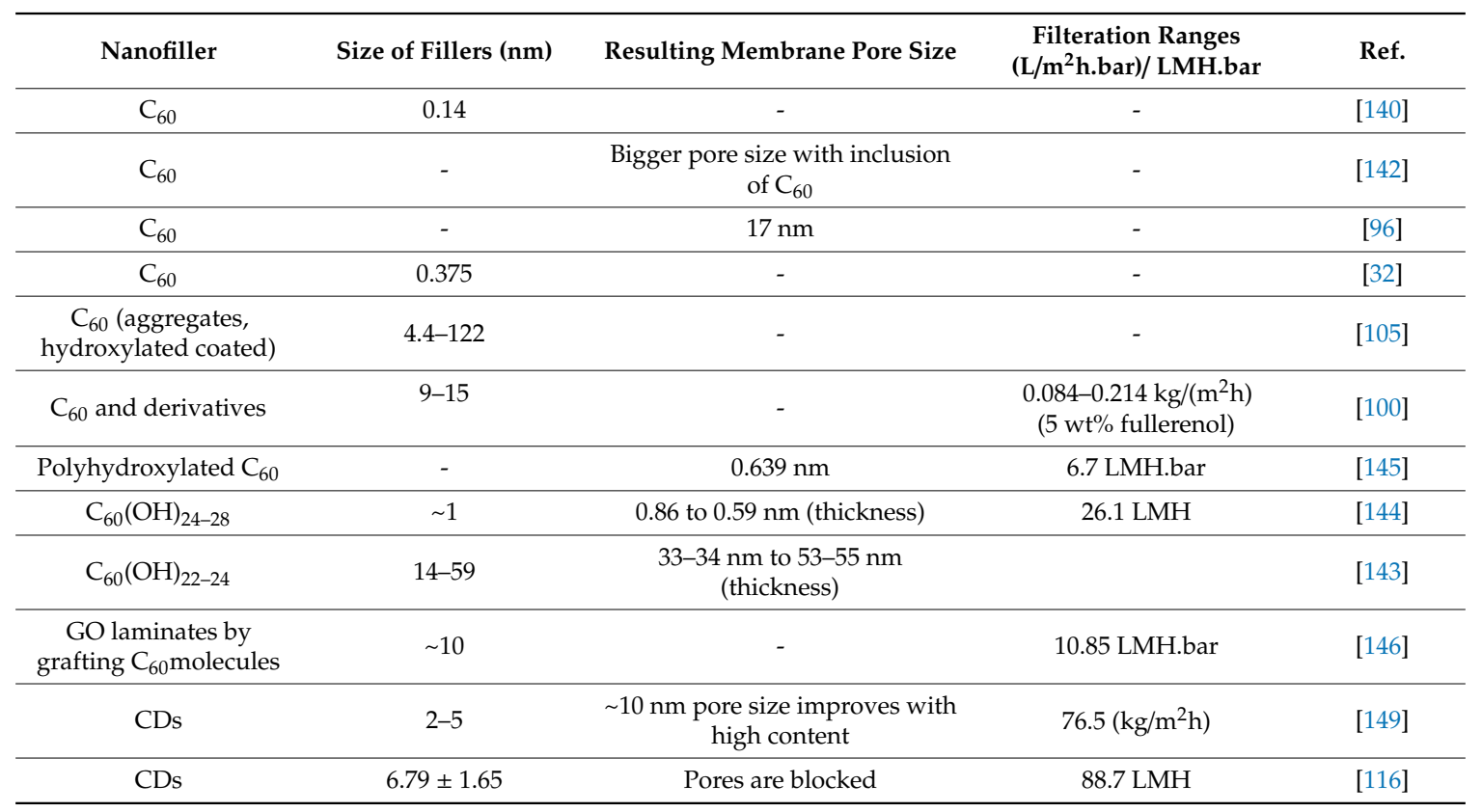


Table 2. Cont

\begin{tabular}{|c|c|c|c|c|}
\hline Nanofiller & Size of Fillers (nm) & Resulting Membrane Pore Size & $\begin{array}{l}\text { Filteration Ranges } \\
\left(\mathrm{L} / \mathrm{m}^{2} \mathrm{~h} \cdot \text { bar }\right) / \text { LMH.bar }\end{array}$ & Ref. \\
\hline CDs & $2-5$ & $>100 \mathrm{~nm}$ & $42.6 \mathrm{LMH}$ & [114] \\
\hline $\begin{array}{c}\text { mesoporous } \\
\text { organosilica embedded } \\
\text { with CDs }\end{array}$ & $\sim 1$ & $\sim 5.50 \mathrm{~nm}$ & - & [147] \\
\hline CQD & 6 & $<2 \mathrm{~nm}$ & 3.6 to 9.72 LMH.bar & [148] \\
\hline CQDs & $3.3-3.4$ & - & $42.1 \mathrm{LMH}$ & [117] \\
\hline CQD & $4-6$ & $\begin{array}{c}\text { pores of CQDs-TFC become } \\
\text { larger while the pores of } \\
\text { PDA-CQDs-TFC becomes } \\
\text { smaller than that of TFC }(0.2-0.8 \\
\mathrm{nm})\end{array}$ & 14.6 LMH.bar & [152] \\
\hline CQD and $\mathrm{Na}+-\mathrm{CQD}$ & 3 and 9 & - & $53 \mathrm{LMH}$ at $23 \mathrm{bar}$ & [115] \\
\hline CQD and $\mathrm{Na}+-\mathrm{CQD}$ & 2 and 6 & - & $57.65 \mathrm{LMH}$ & [150] \\
\hline $\mathrm{Na}+-\mathrm{CQD}$ & avg. 3.5 & $0.5 \mathrm{~nm}$ & $29.8 \mathrm{LMH}$ & [127] \\
\hline $\mathrm{Na}+-\mathrm{CQD}$ & 2.5 to 4 & $\begin{array}{c}0.5 \text { (high composition) } \\
-0.66 \mathrm{~nm} \text { (low composition) }\end{array}$ & 10.4 LMH.bar & [128] \\
\hline $\mathrm{C}_{18}$-CQDs & $38.5 \pm 11.7$ & avg. $200 \mu \mathrm{m}$ & $\begin{array}{l}\left(>600 \mathrm{~L} / \mathrm{m}^{2} \cdot \min ^{1}\right) \\
\text { and water vapor } \\
\left(>145 \mathrm{~kg} / \mathrm{m}^{2} \cdot \mathrm{h}^{1}\right)\end{array}$ & [151] \\
\hline GQD & 2 & $\begin{array}{l}<1.5 \mathrm{~nm} \text { increases with GQD } \\
\text { content }(0 \text { to } 0.39 \mathrm{wt} \%)\end{array}$ & 15 to102 LMH (0.2 Mpa) & [122] \\
\hline GQDs & - & $\begin{array}{l}\text { Fiber diameter decreases with } \\
\text { GQDs to } 279.81 \pm 84.1 \mathrm{~nm}\end{array}$ & 10.8 and $13.6 \mathrm{~kg} / \mathrm{m}^{2} \mathrm{~h}$ & [126] \\
\hline GQDs & 1.9 & $\begin{array}{l}\text { From } 0.77 \text { to } 0.67 \mathrm{~nm} \text { with } \\
\text { increase of GQDs (smaller pores } \\
\text { and narrower pores) }\end{array}$ & 18.3 LMH.MPa & [156] \\
\hline GQDs & $3.4-8.8$ & thickness decreases & $3.35 \pm 0.18$ LMH.bar & [158] \\
\hline GQDs & 2.19 & pore size decreases with GQDs & $12.9 \mathrm{LMH}$ & [159] \\
\hline GQD flakes & $\sim 1.86$ & $\begin{array}{l}0.2 \mathrm{wt} \% \text { and } 0.4 \mathrm{wt} \% \mathrm{GQDs} \\
\text { conc. were } 2.42 \text { and } 2.64 \mathrm{~nm}\end{array}$ & $\begin{array}{l}\text { 244.7 LMH.bar } \\
\text { 5-6 times higher }\end{array}$ & [154] \\
\hline $\begin{array}{l}\text { Amino functionalized } \\
\text { GQDs nanosheets }\end{array}$ & $\sim 1.6$ & $\begin{array}{l}0.74 \text { to } 0.66 \mathrm{~nm} \text { pore size } \\
\text { decreases with GQDS }\end{array}$ & 41 LMH.MPa & [157] \\
\hline GoQDs & $\sim 5.5$ & - & - & [125] \\
\hline GoQDs & $7.5-21$ & - & 37.5 LMH.bar & [160] \\
\hline Nitrogen-doped GoQD & $3-8$ & $>10$ and $30 \mathrm{~nm}$ at interface & $\begin{array}{c}500 \text { to }>3800 \text { LMH while } \\
\text { improving } \\
\text { antibacterial properties }\end{array}$ & [119] \\
\hline GoQDs sheets & $15-20$ & - & $\begin{array}{c}\text { Decreased to } \\
436.2 \pm 27.4 \mathrm{~g} / \mathrm{m}^{2} \mathrm{~h}\end{array}$ & [162] \\
\hline
\end{tabular}

Furthermore, the 0D carbon nano-forms are preferred over other types of fillers as they are ecofriendly, have easy fabrication processes, reduce the environmental pollution and enhance the economic profit. From the above mentioned $0 \mathrm{D}$ carbon fillers for polymer membrane fabrication, the resulting membranes opt to show good antifouling and anti-biofouling properties, more compact and stable structures, durability for long operating times (even at higher temperatures), superior resistance to chemical reagents, desirable surface hydrophilicity/hydrophobicity, enhanced membrane density, low toxicity, and long-term organic solvent stability. These membranes are mostly fabricated for separation (biomolecules, oil-saltwater, selenium and arsenic, metals), self-cleaning, desalination, purification and wastewater treatments.

\section{Conclusions and Future Outlook}

The review presents the fabrication of $0 \mathrm{D}$ carbon nanomaterials such as $\mathrm{C}_{60}$ and CDs used as nanofillers to incorporate them into polymers to form nanocomposite membranes. These carbon 
nanomaterials possess extraordinary properties, biocompatibility, and ease of fabrication, that have proved to be a leap forward in opportunities to revolutionize their potential for desalination and separation processes for wastewater purification. The astonishing performance of $\mathrm{C}_{60}$ or CDs -incorporated into a variety or polymers to form nanocomposite membranes and several approaches adopted to improve the membrane performances is revealed herewith. Numerous efforts have been focused on improving the nanofiller-polymer membrane properties (particularly their water permeability, separation efficiency, and antifouling performances), searching how to efficiently blend these nanofillers into polymers, surface modifications, cost-effectiveness and their long-term stability. It is established that properties of polymer membranes modified by carbon nanomaterials as nanofillers differ markedly from the pristine polymer membranes. To widen the applications, attention must be taken to enhance the polymer nanocomposite membrane stability and separation efficiency, specifically in aggressive and adverse environments, by controlling the loading of carbon nanomaterials, interaction between polymer-carbon nanomaterials, their dispersibility, and other minor parameters are still needed to solve the current problems.

Author Contributions: M.J. contributed for original scientific study and writing, M.N. contributed for thorough scientific review and editing, and J.A.A.-P. contributed for grammatical corrections. All authors have read and agreed to the published version of the manuscript.

Funding: The authors sincerely thank Yachay Tech University, Ecuador for financially supporting this work.

Conflicts of Interest: The authors declare no conflict of interest.

\section{Abbreviations}

$\begin{array}{ll}\text { OD } & \text { zero-dimensional } \\ \mu \mathrm{F} & \text { microfiltration } \\ \mathrm{UF} & \text { ultrafiltration } \\ \mathrm{NF} & \text { nanofiltration } \\ \mathrm{IP} & \text { interfacial polymerization } \\ \mathrm{TFC} & \text { thin-film composite } \\ \mathrm{TFN} & \text { thin-film nanocomposite } \\ \mathrm{C}_{60} & \text { spherical fullerene (buckyball) } \\ \mathrm{nC}_{60} & \text { aggregate spherical fullerene (buckyball) } \\ \mathrm{C}_{60}(\mathrm{OH})_{\mathrm{n}} & \text { fullerenol (hydroxylated } \mathrm{C}_{60} \text { ) } \\ \mathrm{CDs} & \text { carbon dots } \\ \mathrm{CnDs} & \text { carbon nano dots } \\ \mathrm{CQDs} & \text { carbon quantum dots } \\ \mathrm{GQDs} & \text { graphene quantum dots } \\ \text { GoQDs } & \text { graphene oxide quantum dots } \\ \mathrm{CPDs} & \text { carbonized polymer dots } \\ \text { PV } & \text { pervaporation } \\ \text { THF-C } & \text { tetrahydrofuran (control without carbon) } \\ \text { PPO } & \text { polymer-poly (2, 6-dimethyl-1,4-phenylene oxide) } \\ \text { PVP } & \text { poly (vinylpyrrolidone) } \\ \text { PS } & \text { polystyrene } \\ \text { PVF } & \text { poly (vinylidene fluoride) } \\ & \end{array}$

\section{References}

1. Shannon, M.A.; Bohn, P.W.; Elimelech, M.; Georgiadis, J.G.; Mariñas, B.J.; Mayes, A.M. Science and technology for water purification in the coming decades. Nature 2008, 452, 301-310. [CrossRef] [PubMed]

2. Roy, S.; Ragunath, S. Emerging Membrane Technologies for Water and Energy Sustainability: Future Prospects, Constrains and Challenges. Energies 2018, 11, 2997. [CrossRef]

3. Elimelech, M.; Phillip, W.A. The Future of Seawater Desalination: Energy, Technology, and the Environment. Science 2011, 333, 712-717. [CrossRef] [PubMed] 
4. $\quad$ Baker, R.W. Chapter 7: Microfiltration. In Membrane Technology and Applications; John Wiley \& Sons, Ltd.: West Sussex, UK, 2004; Volume 2004, pp. 275-300.

5. Bruggen, B.V.D.; Vandecasteele, C.; Gestel, T.V.; Doyen, W.; Leysen, R. A review of pressure-driven membrane processes in wastewater treatment and drinking water production. Environ. Prog. 2004, 22, 46-56. [CrossRef]

6. Atab, M.S.; Smallbone, A.J.; Roskilly, A.P. An operational and economic study of a reverse osmosis desalination system for potable water and land irrigation. Desalination 2016, 397, 174-184. [CrossRef]

7. Matthews, J.A.; Wnek, G.E.; Simpson, D.G.; Bowlin, G.L. Electrospinning of collagen nanofibers. Biomacromolecules 2002, 3, 232-238. [CrossRef]

8. Lalia, B.S.; Kochkodan, V.; Hashaikeh, R.; Hilal, N. A review on membrane fabrication: Structure, properties and performance relationship. Desalination 2013, 326, 77-95. [CrossRef]

9. Lau, W.J.; Ismail, A.F.; Misdan, N.; Kassim, M.A. A recent progress in thin film composite membrane: A review. Desalination 2012, 287, 190-199. [CrossRef]

10. Ng, L.Y.; Mohammad, A.W.; Leo, C.P.; Hilal, N. Polymeric membranes incorporated with metal/metal oxide nanoparticles: A comprehensive review. Desalination 2013, 308, 15-33. [CrossRef]

11. Chen, P.-C.; Xu, Z.-K. Mineral-Coated Polymer Membranes with Superhydrophilicity and Underwater Superoleophobicity for Effective Oil/Water Separation. Sci. Rep. 2013, 3, 1-6. [CrossRef]

12. van der Marel, P.; Zwijnenburg, A.; Kemperman, A.; Wessling, M.; Temmink, H.; van der Meer, W. Influence of membrane properties on fouling in submerged membrane bioreactors. J. Membr. Sci. 2010, 348, 66-74. [CrossRef]

13. Wang, L.; Yang, S.; Wang, J.; Wang, C.-F.; Chen, L. Fabrication of superhydrophobic TPU film for oil-water separation based on electrospinning route. Mater. Lett. 2011, 65, 869-872. [CrossRef]

14. Seman, M.N.A.; Khayet, M.; Hilal, N. Development of antifouling properties and performance of nanofiltration membranes modified by interfacial polymerization. Desalination 2011, 273, 36-47. [CrossRef]

15. Ba, C.; Economy, J. Preparation and characterization of a neutrally charged antifouling nanofiltration membrane by coating a layer of sulfonated poly(ether ether ketone) on a positively charged nanofiltration membrane. J. Membr. Sci. 2010, 362, 192-201. [CrossRef]

16. Madaeni, S.S.; Zinadini, S.; Vatanpour, V. A new approach to improve antifouling property of PVDF membrane using in situ polymerization of PAA functionalized TiO2 nanoparticles. J. Membr. Sci. 2011, 380, 155-162. [CrossRef]

17. Rana, D.; Kim, Y.; Matsuura, T.; Arafat, H. Development of antifouling thin-film-composite membranes for seawater desalination. J. Membr. Sci. 2011, 367, 110-118. [CrossRef]

18. Wang, C.; Feng, R.; Yang, F. Enhancing the hydrophilic and antifouling properties of polypropylene nonwoven fabric membranes by the grafting of poly(N-vinyl-2-pyrrolidone) via the ATRP method. J. Colloid Interface Sci. 2011, 357, 273-279. [CrossRef]

19. Liu, F.; Abed, M.R.; Li, K. Preparation and characterization of poly(vinylidene fluoride) (PVDF) based ultrafiltration membranes using nano $\gamma-\mathrm{Al}_{2} \mathrm{O}_{3}$. J. Membr. Sci. 2011, 366, 97-103. [CrossRef]

20. Xiang, T.; Zhou, Q.; Li, K.; Li, L.; Su, F.; Qian, B.; Zhao, C. Poly(Acrylic Acid-co-Acrylonitrile) Copolymer Modified Polyethersulfone Hollow Fiber Membrane with pH-Sensitivity. Sep. Sci. Technol. 2010, 45, 2017-2027. [CrossRef]

21. Rahimpour, A.; Madaeni, S.S. Improvement of performance and surface properties of nano-porous polyethersulfone (PES) membrane using hydrophilic monomers as additives in the casting solution. J. Membr. Sci. 2010, 360, 371-379. [CrossRef]

22. Al-anzi, B.S.; Siang, O.C. Recent developments of carbon based nanomaterials and membranes for oily wastewater treatment. RSC Adv. 2017, 7, 20981-20994. [CrossRef]

23. Mona, J.; Perevedentseva, E.; Cheng, C.-L. Chapter 8: Biophysical Interaction of Nanodiamond with Biological Entities In Vivo. In Nanodiamond; Royal Society of Chemistry: Cambridge, UK, 2014; pp. 170-194.

24. Chatterjee, A.; Perevedentseva, E.; Jani, M.; Cheng, C.-Y.; Ye, Y.-S.; Chung, P.-H.; Cheng, C.-L. Antibacterial effect of ultrafine nanodiamond against gram-negative bacteria Escherichia coli. J. Biomed. Opt. 2014, 20, 051014. [CrossRef]

25. Fiorito, S.; Serafino, A.; Andreola, F.; Togna, A.; Togna, G. Toxicity and Biocompatibility of Carbon Nanoparticles. J. Nanosci. Nanotechnol. 2006, 6, 591-599. [CrossRef] [PubMed] 
26. Pramanik, G.; Slegerova, J.; Vanek, V.; Jani, M.; Kindermann, M.; Cigler, P. Chapter 2: Using Polymers to Enhance the Carbon Nanomaterial Biointerface. In Carbon Nanomaterials for Bioimaging, Bioanalysis, and Therapy; John Wiley \& Sons, Ltd.: West Sussex, UK, 2018; pp. 15-42.

27. Williams, C.D.; Carbone, P. Selective Removal of Technetium from Water Using Graphene Oxide Membranes. Environ. Sci. Technol. 2016, 50, 3875-3881. [CrossRef] [PubMed]

28. Zhang, L.; Chen, B.; Ghaffar, A.; Zhu, X. Nanocomposite Membrane with Polyethylenimine-Grafted Graphene Oxide as a Novel Additive to Enhance Pollutant Filtration Performance. Environ. Sci. Technol. 2018, 52, 5920-5930. [CrossRef]

29. Seo, D.H.; Pineda, S.; Woo, Y.C.; Xie, M.; Murdock, A.T.; Ang, E.Y.M.; Jiao, Y.; Park, M.J.; Lim, S.I.; Lawn, M.; et al. Anti-fouling graphene-based membranes for effective water desalination. Nat. Commun. 2018, 9, 1-12.

30. Mojica, M.; Alonso, J.A.; Méndez, F. Synthesis of fullerenes. J. Phys. Org. Chem. 2013, 26, 526-539. [CrossRef]

31. Ruoff, R.S.; Tse, D.S.; Malhotra, R.; Lorents, D.C. Solubility of fullerene (C60) in a variety of solvents. J. Phys. Chem. 1993, 97, 3379-3383. [CrossRef]

32. Penkova, A.; Polotskaya, G.A.; Toikka, A.M.; Trchová, M.; Šlouf, M.; Urbanová, M.; Brus, J.; Brožová, L.; Pientka, Z. Structure and Pervaporation Properties of Poly(phenylene-iso-phthalamide) Membranes Modified by Fullerene C60. Macromol. Mater. Eng. 2009, 294, 432-440. [CrossRef]

33. Hummelen, J.C.; Knight, B.W.; LePeq, F.; Wudl, F.; Yao, J.; Wilkins, C.L. Preparation and Characterization of Fulleroid and Methanofullerene Derivatives. J. Org. Chem. 1995, 60, 532-538. [CrossRef]

34. Periya, V.K.; Koike, I.; Kitamura, Y.; Iwamatsu, S.; Murata, S. Hydrophilic [60] fullerene carboxylic acid derivatives retaining the original 60 $\pi$ electronic system. Tetrahedron Lett. 2004, 45, 8311-8313. [CrossRef]

35. Djordjevic, A.; Srdjenovic, B.; Seke, M.; Petrovic, D.; Injac, R.; Mrdjanovic, J. Review of Synthesis and Antioxidant Potential of Fullerenol Nanoparticles. J. Nanomater. 2015, 2015, 1-15. [CrossRef]

36. Song, Y.; Zhao, X.; Shao, J.; Zhang, J.; Yang, B. The photoluminescence mechanism in carbon dots (graphene quantum dots, carbon nanodots, and polymer dots): Current state and future perspective. Nano Res. 2015, 8, 355-381.

37. Tian, L.; Ghosh, D.; Chen, W.; Pradhan, S.; Chang, X.; Chen, S. Nanosized Carbon Particles From Natural Gas Soot. Chem. Mater. 2009, 21, 2803-2809. [CrossRef]

38. Zhao, Q.-L.; Zhang, Z.-L.; Huang, B.-H.; Peng, J.; Zhang, M.; Pang, D.-W. Facile preparation of low cytotoxicity fluorescent carbon nanocrystals by electrooxidation of graphite. Chem. Commun. 2008, 41, 5116-5118. [CrossRef] [PubMed]

39. Li, H.; He, X.; Kang, Z.; Huang, H.; Liu, Y.; Liu, J.; Lian, S.; Tsang, C.H.A.; Yang, X.; Lee, S.-T. Water-soluble fluorescent carbon quantum dots and photocatalyst design. Angew. Chem. Int. Ed. 2010, 49, 4430-4434. [CrossRef] [PubMed]

40. Ray, S.C.; Saha, A.; Jana, N.R.; Sarkar, R. Fluorescent Carbon Nanoparticles: Synthesis, Characterization, and Bioimaging Application. J. Phys. Chem. C 2009, 113, 18546-18551. [CrossRef]

41. Zhou, J.; Zhou, X.; Li, R.; Sun, X.; Ding, Z.; Cutler, J.; Sham, T.-K. Electronic structure and luminescence center of blue luminescent carbon nanocrystals. Chem. Phys. Lett. 2009, 474, 320-324. [CrossRef]

42. Cayuela, A.; Soriano, M.L.; Carrillo-Carrión, C.; Valcárcel, M. Semiconductor and carbon-based fluorescent nanodots: The need for consistency. Chem. Commun. 2016, 52, 1311-1326. [CrossRef]

43. Wang, X.; Cao, L.; Yang, S.-T.; Lu, F.; Meziani, M.J.; Tian, L.; Sun, K.W.; Bloodgood, M.A.; Sun, Y.-P. Bandgap-Like Strong Fluorescence in Functionalized Carbon Nanoparticles. Angew. Chem. Int. Ed. 2010, 49, 5310-5314. [CrossRef]

44. Pan, D.; Zhang, J.; Li, Z.; Wu, M. Hydrothermal Route for Cutting Graphene Sheets into Blue-Luminescent Graphene Quantum Dots. Adv. Mater. 2010, 22, 734-738. [CrossRef] [PubMed]

45. Tao, S.; Feng, T.; Zheng, C.; Zhu, S.; Yang, B. Carbonized Polymer Dots: A Brand New Perspective to Recognize Luminescent Carbon-Based Nanomaterials. J. Phys. Chem. Lett. 2019, 10, 5182-5188. [CrossRef]

46. Zhao, X.; Tang, Q.; Zhu, S.; Bu, W.; Yang, M.; Liu, X.; Meng, Y.; Yu, W.; Sun, H.; Yang, B. Controllable acidophilic dual-emission fluorescent carbonized polymer dots for selective imaging of bacteria. Nanoscale 2019, 11, 9526-9532. [CrossRef] [PubMed]

47. Baker, S.N.; Baker, G.A. Luminescent Carbon Nanodots: Emergent Nanolights. Angew. Chem. Int. Ed. 2010, 49, 6726-6744. [CrossRef] [PubMed]

48. Roy, P.; Chen, P.-C.; Periasamy, A.P.; Chen, Y.-N.; Chang, H.-T. Photoluminescent carbon nanodots: Synthesis, physicochemical properties and analytical applications. Mater. Today 2015, 18, 447-458. [CrossRef] 
49. Ye, S.-L.; Huang, J.-J.; Luo, L.; Fu, H.-J.; Sun, Y.-M.; Shen, Y.-D.; Lei, H.-T.; Xu, Z.-L. Preparation of Carbon Dots and Their Application in Food Analysis as Signal Probe. Chin. J. Anal. Chem. 2017, 45, 1571-1581. [CrossRef]

50. Hsu, P.-C.; Chang, H.-T. Synthesis of high-quality carbon nanodots from hydrophilic compounds: Role of functional groups. Chem. Commun. 2012, 48, 3984-3986. [CrossRef]

51. Bao, L.; Zhang, Z.-L.; Tian, Z.-Q.; Zhang, L.; Liu, C.; Lin, Y.; Qi, B.; Pang, D.-W. Electrochemical Tuning of Luminescent Carbon Nanodots: From Preparation to Luminescence Mechanism. Adv. Mater. 2011, 23, 5801-5806. [CrossRef]

52. Kong, B.; Zhu, A.; Ding, C.; Zhao, X.; Li, B.; Tian, Y. Carbon Dot-Based Inorganic-Organic Nanosystem for Two-Photon Imaging and Biosensing of $\mathrm{pH}$ Variation in Living Cells and Tissues. Adv. Mater. 2012, 24, 5844-5848. [CrossRef]

53. Zhao, H.X.; Liu, L.Q.; Liu, Z.D.; Wang, Y.; Zhao, X.J.; Huang, C.Z. Highly selective detection of phosphate in very complicated matrixes with an off-on fluorescent probe of europium-adjusted carbon dots. Chem. Commun. 2011, 47, 2604-2606. [CrossRef]

54. Wei, W.; Xu, C.; Ren, J.; Xu, B.; Qu, X. Sensing metal ions with ion selectivity of a crown ether and fluorescence resonance energy transfer between carbon dots and graphene. Chem. Commun. 2012, 48, 1284-1286. [CrossRef]

55. Xiang, Q.; Yu, J.; Jaroniec, M. Graphene-based semiconductor photocatalysts. Chem. Soc. Rev. 2012, 41, 782-796. [CrossRef] [PubMed]

56. Li, R.S.; Gao, P.F.; Zhang, H.Z.; Zheng, L.L.; Li, C.M.; Wang, J.; Li, Y.F.; Liu, F.; Li, N.; Huang, C.Z. Chiral nanoprobes for targeting and long-term imaging of the Golgi apparatus. Chem. Sci. 2017, 8, 6829-6835. [CrossRef] [PubMed]

57. Sharma, V.; Tiwari, P.; Mobin, S.M. Sustainable carbon-dots: Recent advances in green carbon dots for sensing and bioimaging. J. Mater. Chem. B 2017, 5, 8904-8924. [CrossRef] [PubMed]

58. Paul, S.; Gayen, K.; Nandi, N.; Banerjee, A. Carbon nanodot-induced gelation of a histidine-based amphiphile: Application as a fluorescent ink, and modulation of gel stiffness. Chem. Commun. 2018, 54, 4341-4344. [CrossRef] [PubMed]

59. Tsuchiya, T.; Oguri, I.; Yamakoshi, Y.N.; Miyata, N. Novel harmful effects of [60] fullerene on mouse embryos in vitro and in vivo. Fed. Eur. Biochem. Soc. Lett. 1996, 393, 139-145. [CrossRef]

60. Sayes, C.M.; Fortner, J.D.; Guo, W.; Lyon, D.; Boyd, A.M.; Ausman, K.D.; Tao, Y.J.; Sitharaman, B.; Wilson, L.J.; Hughes, J.B.; et al. The Differential Cytotoxicity of Water-Soluble Fullerenes. Nano Lett. 2004, 4, 1881-1887. [CrossRef]

61. Scrivens, W.A.; Tour, J.M.; Creek, K.E.; Pirisi, L. Synthesis of 14C-Labeled C60, Its Suspension in Water, and Its Uptake by Human Keratinocytes. J. Am. Chem. Soc. 1994, 116, 4517-4518. [CrossRef]

62. Moussa, F.; Trivin, F.; Céolin, R.; Hadchouel, M.; Sizaret, P.Y.; Greugny, V.; Fabre, C.; Rassat, A.; Szwarc, H. Early effects of C60 Administration in Swiss Mice: A Preliminary Account for In Vivo C60 Toxicity. Fuller. Sci. Technol. 1996, 4, 21-29. [CrossRef]

63. Jia, G.; Wang, H.; Yan, L.; Wang, X.; Pei, R.; Yan, T.; Zhao, Y.; Guo, A. Cytotoxicity of carbon nanomaterials: Single-wall nanotube, multi-wall nanotube, and fullerene. Environ. Sci. Technol. 2005, 39, 1378-1383. [CrossRef]

64. Cataldo, F.; da Ros, T. Medicinal Chemistry and Pharmacological Potential of Fullerenes and Carbon Nanotubes. Springer Science \& Business Media: Dordrecht, The Netherlands, 2008.

65. Bosi, S.; da Ros, T.; Castellano, S.; Banfi, E.; Prato, M. Antimycobacterial activity of ionic fullerene derivatives. Bioorg. Med. Chem. Lett. 2000, 10, 1043-1045. [CrossRef]

66. Tsao, N.; Kanakamma, P.P.; Luh, T.-Y.; Chou, C.-K.; Lei, H.-Y. Inhibition of Escherichia coli-Induced Meningitis by Carboxyfullerence. Antimicrob. Agents Chemother. 1999, 43, 2273-2277. [CrossRef] [PubMed]

67. Tsao, N.; Luh, T.-Y.; Chou, C.-K.; Wu, J.-J.; Lin, Y.-S.; Lei, H.-Y. Inhibition of Group A Streptococcus Infection by Carboxyfullerene. Antimicrob. Agents Chemother. 2001, 45, 1788-1793. [CrossRef] [PubMed]

68. Brant, J.; Lecoanet, H.; Hotze, M.; Wiesner, M. Comparison of Electrokinetic Properties of Colloidal Fullerenes (n-C60) Formed Using Two Procedures. Environ. Sci. Technol. 2005, 39, 6343-6351. [CrossRef] [PubMed]

69. Lyon, D.Y.; Fortner, J.D.; Sayes, C.M.; Colvin, V.L.; Hughes, J.B. Bacterial cell association and antimicrobial activity of a C60 water suspension. Environ. Toxicol. Chem. 2005, 24, 2757-2762. [CrossRef] 
70. Fortner, J.D.; Lyon, D.Y.; Sayes, C.M.; Boyd, A.M.; Falkner, J.C.; Hotze, E.M.; Alemany, L.B.; Tai, Y.J.; Guo, W.; Ausman, K.D.; et al. C60 in Water: Nanocrystal Formation and Microbial Response. Environ. Sci. Technol. 2005, 39, 4307-4316. [CrossRef]

71. Nyberg, L.; Turco, R.F.; Nies, L. Assessing the Impact of Nanomaterials on Anaerobic Microbial Communities. Environ. Sci. Technol. 2008, 42, 1938-1943. [CrossRef]

72. Tong, Z.; Bischoff, M.; Nies, L.; Applegate, B.; Turco, R.F. Impact of Fullerene (C60) on a Soil Microbial Community. Environ. Sci. Technol. 2007, 41, 2985-2991. [CrossRef]

73. Moussa, F.; Chretie, P.; Dubois, P.; Chuniaud, L.; Dessante, M.; Trivin, F.; Sizaret, P.-Y.; Agafonov, V.; Céolin, R.; Szwarc, H.; et al. The Influence of C60 Powders On Cultured Human Leukocytes. Fuller. Sci. Technol. 1995, 3, 333-342. [CrossRef]

74. Moussa, F.; Chrétien, P.; Pressac, M.; Trivin, F.; Szwarc, H.; Céolin, R. Preliminary Study of the Influence of Cubic C60 on Cultured Human Monocytes: Lack of Interleukin-1 ß Secretion. Fuller. Sci. Technol. 1997, 5, 503-510. [CrossRef]

75. Baierl, T.; Drosselmeyer, E.; Seidel, A.; Hippeli, S. Comparison of immunological effects of Fullerene C60 and raw soot from Fullerene production on alveolar macrophages and macrophage like cells in vitro. Exp. Toxicol. Pathol. 1996, 48, 508-511. [CrossRef]

76. Wolff, D.J.; Papoiu, A.D.P.; Mialkowski, K.; Richardson, C.F.; Schuster, D.I.; Wilson, S.R. Inhibition of Nitric Oxide Synthase Isoforms by Tris-Malonyl-C60-Fullerene Adducts. Arch. Biochem. Biophys. 2000, 378, $216-223$. [CrossRef] [PubMed]

77. Wolff, D.J.; Mialkowski, K.; Richardson, C.F.; Wilson, S.R. C60-Fullerene monomalonate adducts selectively inactivate neuronal nitric oxide synthase by uncoupling the formation of reactive oxygen intermediates from nitric oxide production. Biochemistry 2001, 40, 37-45. [CrossRef] [PubMed]

78. Huczko, A.; Lange, H.; Calko, E. Short Communication: Fullerenes: Experimental Evidence for a Null Risk of Skin Irritation and Allergy. Fullererene Sci. Technol. 1999, 7, 935-939. [CrossRef]

79. Rancan, F.; Rosan, S.; Boehm, F.; Cantrell, A.; Brellreich, M.; Schoenberger, H.; Hirsch, A.; Moussa, F. Cytotoxicity and photocytotoxicity of a dendritic $\mathrm{C}(60)$ mono-adduct and a malonic acid $\mathrm{C}(60)$ tris-adduct on Jurkat cells. J. Photochem. Photobiol. B 2002, 67, 157-162. [CrossRef]

80. Sayes, C.M.; Gobin, A.M.; Ausman, K.D.; Mendez, J.; West, J.L.; Colvin, V.L. Nano-C60 cytotoxicity is due to lipid peroxidation. Biomaterials 2005, 26, 7587-7595. [CrossRef] [PubMed]

81. Yáñez-Sedeño, P.; Campuzano, S.; Pingarrón, J.M. Fullerenes in Electrochemical Catalytic and Affinity Biosensing: A Review. C-J. Carbon Res. 2017, 3, 21.

82. Cha, C.; Shin, S.R.; Annabi, N.; Dokmeci, M.R.; Khademhosseini, A. Carbon-Based Nanomaterials: Multifunctional Materials for Biomedical Engineering. Acs Nano 2013, 7, 2891-2897. [CrossRef]

83. Pilehvar, S.; de Wael, K. Recent Advances in Electrochemical Biosensors Based on Fullerene-C60 Nano-Structured Platforms. Biosensors 2015, 5, 712-735. [CrossRef]

84. Narayan, R. Nanobiomaterials: Nanostructured Materials for Biomedical Applications; Woodhead Publishing: Amsterdam, The Netherlands, 2017.

85. Partha, R.; Conyers, J.L. Biomedical applications of functionalized fullerene-based nanomaterials. Int. J. Nanomed. 2009, 4, 261-275.

86. Li, Q.; Chen, B.; Xing, B. Aggregation Kinetics and Self-Assembly Mechanisms of Graphene Quantum Dots in Aqueous Solutions: Cooperative Effects of $\mathrm{pH}$ and Electrolytes. Environ. Sci. Technol. 2017, 51, 1364-1376. [CrossRef]

87. Ron, H. "A Toxicologic Review of Quantum Dots: Toxicity Depends on Physicochemical and Environmental Factors. Environ. Health Perspect. 2006, 114, 165-172.

88. Nurunnabi, M.; Khatun, Z.; Huh, K.M.; Park, S.Y.; Lee, D.Y.; Cho, K.J.; Lee, Y.-K. In Vivo Biodistribution and Toxicology of Carboxylated Graphene Quantum Dots. Acs Nano 2013, 7, 6858-6867. [CrossRef] [PubMed]

89. Wang, Y.; Anilkumar, P.; Cao, L.; Liu, J.-H.; Luo, P.G.; Tackett, K.N.; Sahu, S.; Wang, P.; Wang, X.; Sun, Y.-P. Carbon dots of different composition and surface functionalization: Cytotoxicity issues relevant to fluorescence cell imaging. Exp. Biol. Med. 2011, 236, 1231-1238. [CrossRef]

90. Yang, S.-T.; Wang, X.; Wang, H.; Lu, F.; Luo, P.G.; Cao, L.; Meziani, M.J.; Liu, J.-H.; Liu, Y.; Chen, M.; et al. Carbon Dots as Nontoxic and High-Performance Fluorescence Imaging Agents. J. Phys. Chem. C Nanomater. Interfaces 2009, 113, 18110-18114. [CrossRef] [PubMed] 
91. Li, N.; Liang, X.; Wang, L.; Li, Z.; Li, P.; Zhu, Y.; Song, J. Biodistribution study of carbogenic dots in cells and in vivo for optical imaging. J. Nano. Res. 2012, 14, 1177. [CrossRef]

92. Wang, J.; Qiu, J. A review of carbon dots in biological applications. J. Mater. Sci. 2016, 51, 4728-4738. [CrossRef]

93. Huang, X.D.; Goh, S.H. Miscibility of C60-end-capped poly(ethylene oxide) with poly(vinyl chloride). Polymer 2002, 43, 1417-1421. [CrossRef]

94. Huang, X.D.; Goh, S.H. Interpolymer Complexes through Hydrophobic Interactions: C60-End-Capped Poly(ethylene oxide)/Poly(methacrylic acid) Complexes. Macromolecules 2000, 33, 8894-8897. [CrossRef]

95. Polotskaya, G.A.; Andreeva, D.V.; El'yashevich, G.K. Investigation of gas diffusion through films of fullerene-containing poly(phenylene oxide). Tech. Phys. Lett. Phys. Lett. 1999, 25, 555-557. [CrossRef]

96. Sudareva, N. "Properties of casting solutions and ultrafiltration membranes based on fullerene-polyamide nanocomposites. Express Polym. Lett. 2012, 6, 178-188. [CrossRef]

97. Yang, M.; Zhao, C.; Zhang, S.; Li, P.; Hou, D. Preparation of graphene oxide modified poly(m-phenylene isophthalamide) nanofiltration membrane with improved water flux and antifouling property. Appl. Surf. Sci. 2017, 394, 149-159. [CrossRef]

98. Lin, C.-E.; Wang, J.; Zhou, M.-Y.; Zhu, B.-K.; Zhu, L.-P.; Gao, C.-J. Poly(m-phenylene isophthalamide) (PMIA): A potential polymer for breaking through the selectivity-permeability trade-off for ultrafiltration membranes. J. Membr. Sci. 2016, 518, 72-78. [CrossRef]

99. Shawky, H. "Performance of aromatic polyamide RO membranes synthesized by interfacial polycondensation process in a water-tetrahydrofuran system. J. Membr. Sci. 2009, 339, 209-214. [CrossRef]

100. Dmitrenko, M.E.; Penkova, A.V.; Kuzminova, A.I.; Atta, R.R.; Zolotarev, A.A.; Mazur, A.S.; Vezo, O.S.; Lahderanta, E.; Markelov, D.A.; Ermakov, S.S. Development and investigation of novel polyphenylene isophthalamide pervaporation membranes modified with various fullerene derivatives. Sep. Purif. Technol. 2019, 2019, 226. [CrossRef]

101. Penkova, A.; Toikka, A.; Kostereva, T.; Sudareva, N.; Polotskaya, G. Structure and Transport Properties of Fullerene-Polyamide Membranes. Fuller. Nanotub. Carbon Nanostruct. 2008, 16, 666-669. [CrossRef]

102. Tarabukina, E.; Krasnov, I.; Ratnikova, O.; Melenevskaya, E.; Filippov, A. Effect of Centrifugal Field upon Hydrodynamic Characteristics of Fullerene C60 and Poly(N-vinylpyrrolidone) Complex in Aqueous Solutions. Int. J. Polym. Anal. Charact. 2007, 12, 203-220. [CrossRef]

103. Sushko, M.L.; Tenhu, H.; Klenin, S.I. Static and dynamic light scattering study of strong intermolecular interactions in aqueous solutions of PVP/C60 complexes. Polymer 2002, 43, 2769-2775. [CrossRef]

104. Chubarova, E.; Melenevskaya, E.; Sudareva, N.; Andreeva, O.; Malachova, I.; Ratnikova, O. Degradation of Macromolecular Chains in Fullerene C60-Polystyrene Composites. J. Macromol. Sci. Part B 2005, 44, 455-469. [CrossRef]

105. Brunet, L.; Lyon, D.Y.; Hotze, E.M.; Alvarez, P.J.J.; Wiesner, M.R. Comparative Photoactivity and Antibacterial Properties of C60 Fullerenes and Titanium Dioxide Nanoparticles. Environ. Sci. Technol. 2009, 43, 4355-4360. [CrossRef]

106. Tasaki, K.; Gasa, J.; Wang, H.; DeSousa, R. Fabrication and characterization of fullerene-Nafion composite membranes. Polymer 2007, 48, 4438-4448. [CrossRef]

107. Phillips, J.P.; Deng, X.; Stephen, R.R.; Fortenberry, E.L.; Todd, M.L.; McClusky, D.M.; Stevenson, S.; Misra, R.; Morgan, S.; Long, T.E. Nano- and bulk-tack adhesive properties of stimuli-responsive, fullerene-polymer blends, containing polystyrene-block-polybutadiene-block-polystyrene and polystyreneblock-polyisoprene-block-polystyrene rubber-based adhesives. Polymer 2007, 48, 6773-6781. [CrossRef]

108. Li, F.; Li, Y.; Ge, Z.; Zhu, D.; Song, Y.; Fang, G. Synthesis and optical limiting properties of polycarbonates containing fullerene derivative. J. Phys. Chem. Solids 2000, 61, 1101-1103. [CrossRef]

109. Zhang, F.; Svensson, M.; Andersson, M.R.; Maggini, M.; Bucella, S.; Menna, E.; Inganäs, O. Soluble Polythiophenes with Pendant Fullerene Groups as Double Cable Materials for Photodiodes. Adv. Mater. 2001, 13, 1871-1874. [CrossRef]

110. Chen, Y.; Hunc, Z.-E.; Cai, R.-F.; Kong, S.-Q.; Chen, S.; Shao, Z.Q.; Yan, X.; Zhao, F.; Fu, D. Synthesis and characterization of soluble C60-chemically modified poly(p-bromostyrene). J. Polym. Sci. Part A Polym. Chem. 1996, 34, 3297-3302. [CrossRef]

111. Cai, R.-F.; Bai, X.; Chen, Y.; Huang, Z.-E. Preparation and structural characterization of C70 chemically modified poly(N-vinylcarbazole). Eur. Polym. J. 1998, 34, 7-12. [CrossRef] 
112. Dai, L.; Mau, A.; Griesser, H.; Spurling, T.; White, J. Grafting of Buckminsterfullerene onto Polydiene: A New Route to Fullerene-Containing Polymers. J. Phys. Chem. 1995, 99, 17302-17304. [CrossRef]

113. Bergbreiter, D.E.; Gray, H.N. Grafting of C60 onto polyethylene surfaces. J. Chem. Soc. Chem. Commun. 1993, 7,645-646. [CrossRef]

114. Yuan, Z.; Wu, X.; Jiang, Y.; Li, Y.; Huang, J.; Hao, L.; Zhang, J.; Wang, J. Carbon dots-incorporated composite membrane towards enhanced organic solvent nanofiltration performance. J. Membr. Sci. 2018, 549, 1-11. [CrossRef]

115. Gai, W.; Zhao, D.L.; Chung, T.-S. Novel thin film composite hollow fiber membranes incorporated with carbon quantum dots for osmotic power generation. J. Membr. Sci. 2018, 551, 94-102. [CrossRef]

116. Li, Y.; Li, S.; Zhang, K. Influence of hydrophilic carbon dots on polyamide thin film nanocomposite reverse osmosis membranes. J. Membr. Sci. 2017, 537, 42-53. [CrossRef]

117. Sun, H.; Wu, P. Tuning the functional groups of carbon quantum dots in thin film nanocomposite membranes for nanofiltration. J. Membr. Sci. 2018, 564, 394-403. [CrossRef]

118. Wang, R.; Lu, K.-Q.; Tang, Z.-R.; Xu, Y.-J. Recent progress on carbon quantum dots: Synthesis, properties and applications in photocatalysis. J. Mater. Chem. 2017, 8, 5. [CrossRef]

119. Fathizadeh, M.; Tien, H.N.; Khivantsev, K.; Song, Z.; Zhou, F.; Yu, M. Polyamide/nitrogen-doped graphene oxide quantum dots (N-GOQD) thin film nanocomposite reverse osmosis membranes for high flux desalination. Desalination 2019, 451, 125-132. [CrossRef]

120. Jiang, Y.; Chung, T.S.; Cao, C.; Huang, Z.; Kulprathipanja, S. Fundamental understanding of nano-sized zeolite distribution in the formation of the mixed matrix single- and dual-layer asymmetric hollow fiber membranes. J. Membr. Sci. 2005, 252, 89-100. [CrossRef]

121. Vrijenhoek, E.; Hong, S.; Elimelech, M. Influence of Membrane Surface Properties on Initial Rate of Colloidal Fouling of Reverse Osmosis and Nanofiltration Membranes. J. Membr. Sci. 2001, 188, 115-128. [CrossRef]

122. Bi, R.; Zhang, Q.; Zhang, R.; Su, Y.; Jiang, Z. Thin film nanocomposite membranes incorporated with graphene quantum dots for high flux and antifouling property. J. Membr. Sci. 2018, 553, 17-24. [CrossRef]

123. Zhao, D.L.; Das, S.; Chung, T.-S. Carbon Quantum Dots Grafted Antifouling Membranes for Osmotic Power Generation via Pressure-Retarded Osmosis Process. Environ. Sci. Technol. 2017, 51, 14016-14023. [CrossRef]

124. Kang, G.; Cao, Y. Application and modification of poly(vinylidene fluoride) (PVDF) membranes - A review. J. Membr. Sci. 2014, 463, 145-165. [CrossRef]

125. Zeng, Z.; Yu, D.; He, Z.; Liu, J.; Xiao, F.-X.; Zhang, Y.; Wang, R.; Bhattacharyya, D.; Tan, T.T.Y. Graphene Oxide Quantum Dots Covalently Functionalized PVDF Membrane with Significantly-Enhanced Bactericidal and Antibiofouling Performances. Sci. Rep. 2016, 6, 20142-20152. [CrossRef]

126. Jafari, A.; Kebria, M.R.S.; Rahimpour, A.; Bakeri, G. Graphene quantum dots modified polyvinylidenefluride (PVDF) nanofibrous membranes with enhanced performance for air Gap membrane distillation. Chem. Eng. Process. 2018, 126, 222-231. [CrossRef]

127. Guo, C.X.; Zhao, D.; Zhao, Q.; Wang, P.; Lu, X. Na+-functionalized carbon quantum dots: A new draw solute in forward osmosis for seawater desalination. Chem. Commun. 2014, 50, 7318-7321. [CrossRef] [PubMed]

128. He, Y.; Zhao, D.L.; Chung, T.-S. Na+ functionalized carbon quantum dot incorporated thin-film nanocomposite membranes for selenium and arsenic removal. J. Membr. Sci. 2018, 564, 483-491. [CrossRef]

129. Pal, A.; Sk, M.P.; Chattopadhyay, A. Conducting Carbon Dot-Polypyrrole Nanocomposite for Sensitive Detection of Picric acid. ACS Appl. Mater. Interfaces 2016, 8, 5758-5762. [CrossRef] [PubMed]

130. Safaie, B.; Youssefi, M.; Rezaei, B.; Irannejad, N. Synthesis and Properties of Photoluminescent Carbon Quantum Dot/Polyacrylonitrile Composite Nanofibers. Smart Sci. 2017, 6, 1-8. [CrossRef]

131. Pendergast, M.M.; Hoek, E.M.V. A review of water treatment membrane nanotechnologies. Energy Environ. Sci. 2011, 4, 1946-1971. [CrossRef]

132. Mueller, N.C.; Bruggen, B.; Keuter, V.; Luis, P.; Melin, T.; Pronk, W.; Reisewitz, R.; Rickerby, D.; Riosh, G.M.; Wennekes, W.; et al. Nanofiltration and nanostructured membranes-Should they be considered nanotechnology or not? J. Hazard. Mater. 2012, 211-212, 275-280. [CrossRef]

133. Qu, X.; Brame, J.; Li, Q.; Alvarez, P.J.J. Nanotechnology for a Safe and Sustainable Water Supply: Enabling Integrated Water Treatment and Reuse. Acc. Chem. Res. 2013, 46, 834-843. [CrossRef]

134. Ma, S.; Zhan, S.; Jia, Y.; Zhou, Q. Highly Efficient Antibacterial and Pb(II) Removal Effects of Ag-CoFe2O4-GO Nanocomposite. ACS Appl. Mater. Interfaces 2015, 7, 10576-10586. [CrossRef] 
135. Zhao, G.; Li, J.; Ren, X.; Chen, C.; Wang, X. Few-Layered Graphene Oxide Nanosheets As Superior Sorbents for Heavy Metal Ion Pollution Management. Environ. Sci. Technol. 2011, 45, 10454-10462. [CrossRef]

136. Zhang, B.-T.; Zheng, X.; Li, H.-F.; Lin, J.-M. Application of carbon-based nanomaterials in sample preparation: A review. Anal. Chim. Acta 2013, 784, 1-17. [CrossRef] [PubMed]

137. Valcárcel, M.; Cárdenas, S.; Simonet, B.M.; Moliner-Martínez, Y.; Lucena, R. Carbon Nanostructures as Sorbent Materials in Analytical Processes. Trends Anal. Chem. Trac. 2008, 27, 34-43.

138. Samonin, V.V.; Nikonova, V.Y.; Podvyaznikov, M.L. Carbon adsorbents on the basis of the hydrolytic lignin modified with fullerenes in producing. Russ. J. Appl. Chem. 2014, 87, 190-193. [CrossRef]

139. Ma, J.; Guo, Q.; Gao, H.-L.; Qin, X. Synthesis of C60/Graphene Composite as Electrode in Supercapacitors. Fullererenes Nanotub. Carbon Nanostructures 2015, 23, 477-482. [CrossRef]

140. Alekseeva, O.V.; Bagrovskaya, N.A.; Noskov, A.V. Sorption of heavy metal ions by fullerene and polystyrene/fullerene film compositions. Prot. Met. Phys. Chem. Surf. 2016, 52, 443-447. [CrossRef]

141. Samonin, V.V.; Nikonova, V.Y.; Podvyaznikov, M.L. Sorption properties of fullerene-modified activated carbon with respect to metal ions. Prot. Met. 2008, 44, 190-192. [CrossRef]

142. Jin, X.; Hu, J.Y.; Tint, M.L.; Ong, S.L.; Biryulin, Y.; Polotskaya, G. Estrogenic compounds removal by fullerene-containing membranes. Desalination 2007, 214, 83-90. [CrossRef]

143. Plisko, T.V.; Liubimova, A.S.; Bildyukevich, A.V.; Penkova, A.V.; Dmitrenko, M.E.; Mikhailovskii, V.Y.; Melnikova, G.B.; Semenov, K.N.; Doroshkevich, N.V.; Kuzminova, A.I. Fabrication and characterization of polyamide-fullerenol thin film nanocomposite hollow fiber membranes with enhanced antifouling performance. J. Membr. Sci. 2018, 551, 20-36. [CrossRef]

144. Perera, M.G.N.; Galagedara, Y.R.; Ren, Y.; Jayaweera, M.; Zhao, Y.; Weerasooriya, R. Fabrication of fullerenol-incorporated thin-film nanocomposite forward osmosis membranes for improved desalination performances. J. Polym. Res. 2018, 25, 199. [CrossRef]

145. Shen, Q.; Xu, S.-J.; Xu, Z.-L.; Zhang, H.-Z.; Dong, Z.-Q. Novel thin-film nanocomposite membrane with water-soluble polyhydroxylated fullerene for the separation of $\mathrm{Mg} 2+/ \mathrm{Li}+$ aqueous solution. J. Appl. Polym. Sci. 2019, 136, 48029. [CrossRef]

146. Liu, Y.; Phillips, B.; Li, W.; Zhang, Z.; Fang, L.; Qiu, J.; Wang, S. Fullerene-Tailored Graphene Oxide Interlayer Spacing for Energy-Efficient Water Desalination. Acs Appl. Nanomater. 2018, 1, 6168-6175. [CrossRef]

147. Wang, L.; Cheng, C.; Tapas, S.; Lei, J.; Matsuoka, M.; Zhang, J.; Zhang, F. Carbon dots modified mesoporous organosilica as an adsorbent for the removal of 2,4-dichlorophenol and heavy metal ions. J. Mater. Chem. A 2015, 3, 13357-13364. [CrossRef]

148. Yang, W.-J.; Shao, D.-D.; Zhou, Z.; Xia, Q.-C.; Chen, J.; Cao, X.-L.; Zheng, T.; Sun, S.-P. Carbon quantum dots (CQDs) nanofiltration membranes towards efficient biogas slurry valorization. Chem. Eng. J. 2020, 385, 123993. [CrossRef]

149. Koulivand, H.; Shahbazi, A.; Vatanpour, V.; Rahmandoust, M. Development of carbon dot-modified polyethersulfone membranes for enhancement of nanofiltration, permeation and antifouling performance. Sep. Purif. Technol. 2020, 230, 115895. [CrossRef]

150. Gai, W.; Zhao, D.L.; Chung, T.-S. Thin film nanocomposite hollow fiber membranes comprising $\mathrm{Na}$-functionalized carbon quantum dots for brackish water desalination. Water Res. 2019, 154, 54-61. [CrossRef] [PubMed]

151. Lei, S.; Zeng, M.; Huang, D.; Wang, L.; Zhang, L.; Xi, B.; Ma, W.; Chen, G.; Cheng, Z. Synergistic High-flux Oil-Saltwater Separation and Membrane Desalination with Carbon Quantum Dots Functionalized Membrane. ACS Sustain. Chem. Eng. 2019, 7, 13708-13716. [CrossRef]

152. Shao, D.-D.; Yang, W.J.; Xiao, H.-F.; Wang, Z.-Y.; Zhou, C.; Cao, X.-L.; Sun, S.-P. Self-Cleaning Nanofiltration Membranes by Coordinated Regulation of Carbon Quantum Dots and Polydopamine. ACS Appl. Mater. Interfaces 2020, 12, 580-590. [CrossRef]

153. Punrat, E.; Maksuk, C.; Chuanuwatanakul, S.; Wonsawat, W.; Chailapakul, O. Polyaniline/graphene quantum dot-modified screen-printed carbon electrode for the rapid determination of $\mathrm{Cr}(\mathrm{VI})$ using stopped-flow analysis coupled with voltammetric technique. Talanta 2016, 150, 198-205. [CrossRef]

154. Bi, R.; Zhang, R.; Shen, J.; Liu, Y.; He, M.; You, X.; Su, Y.; Jiang, Z. Graphene quantum dots engineered nanofiltration membrane for ultrafast molecular separation. J. Membr. Sci. 2019, 572, 504-511. [CrossRef] 
155. Wu, X.; Zhou, G.; Cui, X.; Li, Y.; Wang, J.; Cao, X.; Zhang, P. Nanoparticle-Assembled Thin Film with Amphipathic Nanopores for Organic Solvent Nanofiltration. ACS Appl. Mater. Interfaces 2019, 11, 17804-17813. [CrossRef]

156. Li, S.; Li, C.; Song, X.; Su, B.; Prasad, B.M.B.; Gao, X.; Gao, C. Graphene Quantum Dots-Doped Thin Film Nanocomposite Polyimide Membranes with Enhanced Solvent Resistance for Solvent-Resistant Nanofiltration. ACS Appl. Mater. Interfaces 2019, 11, 6527-6540. [CrossRef] [PubMed]

157. Li, S.; Li, C.; Su, B.; Hu, M.Z.; Gao, X.; Gao, C. Amino-functionalized graphene quantum dots (aGQDs)-embedded thin film nanocomposites for solvent resistant nanofiltration (SRNF) membranes based on covalence interactions. J. Membr. Sci. 2019, 588, 117212. [CrossRef]

158. Seyedpour, S.F.; Rahimpour, A.; Shamsabadi, A.A.; Soroush, M. Improved performance and antifouling properties of thin-film composite polyamide membranes modified with nano-sized bactericidal graphene quantum dots for forward osmosis. Chem. Eng. Res. Des. 2018, 139, 321-334. [CrossRef]

159. Xu, S.; Li, F.; Su, B.; Hu, M.Z.; Gao, X.; Gao, C. Novel graphene quantum dots (GQDs)-incorporated thin film composite (TFC) membranes for forward osmosis (FO) desalination. Desalination 2019, 451, 219-230. [CrossRef]

160. Song, X.; Zhou, Q.; Zhang, T.; Xu, H.; Wang, Z. Pressure-assisted preparation of graphene oxide quantum dot-incorporated reverse osmosis membranes: Antifouling and chlorine resistance potentials. J. Mater. Chem. A 2016, 4, 16896-16905. [CrossRef]

161. Zhang, C.; Wei, K.; Zhang, W.; Bai, Y.; Sun, Y.; Gu, J. Graphene Oxide Quantum Dots Incorporated into a Thin Film Nanocomposite Membrane with High Flux and Antifouling Properties for Low-Pressure Nanofiltration. ACS Appl. Mater. Interfaces 2017, 9, 11082-11094. [CrossRef]

162. Lecaros, R.L.G.; Deseo, K.M.; Hung, W.-S.; Tayo, L.L.; Hu, C.-C.; An, Q.-F.; Tsai, H.-A.; Lee, K.-R.; Lai, J.-Y. Influence of integrating graphene oxide quantum dots on the fine structure characterization and alcohol dehydration performance of pervaporation composite membrane. J. Membr. Sci. 2019, 576, 36-47. [CrossRef]

Publisher's Note: MDPI stays neutral with regard to jurisdictional claims in published maps and institutional affiliations.

(C) 2020 by the authors. Licensee MDPI, Basel, Switzerland. This article is an open access article distributed under the terms and conditions of the Creative Commons Attribution (CC BY) license (http://creativecommons.org/licenses/by/4.0/). 